\title{
Assessment of the Safe Consumption of Nuts in Terms of the Content of Toxic Elements with Chemometric Analysis
}

\author{
Joanna Bielecka ${ }^{\dagger}$, Anna Puścion-Jakubik*,+D, Renata Markiewicz-Żukowska (D), Jolanta Soroczyńska, \\ Patryk Nowakowski (D), Monika Grabia (D), Konrad Mielcarek (D), Klaudia Przebierowska, Klaudia Kotowska \\ and Katarzyna Socha (D)
}

check for updates

Citation: Bielecka, J.;

Puścion-Jakubik, A.;

Markiewicz-Żukowska, R.; Soroczyńska, J.; Nowakowski, P.; Grabia, M.; Mielcarek, K.;

Przebierowska, K.; Kotowska, K.;

Socha, K. Assessment of the Safe Consumption of Nuts in Terms of the Content of Toxic Elements with Chemometric Analysis. Nutrients 2021, 13, 3606. https://doi.org/ $10.3390 /$ nu13103606

Academic Editor: Hajo Haase

Received: 4 September 2021

Accepted: 12 October 2021

Published: 14 October 2021

Publisher's Note: MDPI stays neutral with regard to jurisdictional claims in published maps and institutional affiliations.

Copyright: (c) 2021 by the authors. Licensee MDPI, Basel, Switzerland. This article is an open access article distributed under the terms and conditions of the Creative Commons Attribution (CC BY) license (https:// creativecommons.org/licenses/by/ $4.0 /)$.
Department of Bromatology, Faculty of Pharmacy with the Division of Laboratory Medicine, Medical University of Białystok, Mickiewicza 2D Street, 15-222 Białystok, Poland; joanna.bielecka@umb.edu.pl (J.B.); renmar@poczta.onet.pl (R.M.-Ż.); jolanta.soroczynska@umb.edu.pl (J.S.); patryk.nowakowski@umb.edu.pl (P.N.); monika.grabia@umb.edu.pl (M.G.); konrad.mielcarek@umb.edu.pl (K.M.); klaudia130@gmail.com (K.P.); klaudiakkotowska@gmail.com (K.K.); katarzyna.socha@umb.edu.pl (K.S.)

* Correspondence: anna.puscion-jakubik@umb.edu.pl; Tel.: +48-8574-854-69

+ These authors contributed equally to this work.

Abstract: Nuts are characterized by high nutritional value and are recommended as a part of a healthy diet. At the same time, toxic elements could also be found in them. In this research, we measured the content of $\mathrm{As}, \mathrm{Cd}, \mathrm{Pb}$ and $\mathrm{Hg}$ in a wide variety of edible nuts. To determine the $\mathrm{As}$ content, inductively coupled plasma mass spectrometry (ICP-MS) was applied. Cd and Pb were detected by the electrothermal atomic absorption spectrometry analytical technique (ETAAS) with Zeeman background correction, while atomic absorption spectrometry method (AAS) with the amalgamation technique in the case of $\mathrm{Hg}$ was used. The study material consisted of 120 samples without replications (10 for each subgroup) including the following nuts: Almonds, Brazil nuts, cashew nuts, hazelnuts, macadamia nuts, peanuts, pecan nuts, pine nuts, pistachios and walnuts. Indicators such as the target hazard quotient (THQ), cancer risk (CR) and hazard index (HI) were used to assess the health risk. The highest median $\mathrm{As}, \mathrm{Cd}, \mathrm{Pb}$ and $\mathrm{Hg}$ contents were observed for pistachios $(192.42 \mu \mathrm{g} / \mathrm{kg})$, pine nuts $(238.40 \mu \mathrm{g} / \mathrm{kg})$, peanuts $(82.06 \mu \mathrm{g} / \mathrm{kg})$ and pecans $(82.06 \mu \mathrm{g} / \mathrm{kg})$, respectively. The exceedance of the established limits was found in the case of $\mathrm{Pb}$ for nine samples: macadamia nuts $(221.49 \mu \mathrm{g} / \mathrm{kg} ; 2350.94 \mu \mathrm{g} / \mathrm{kg} ; 2581.43 \mu \mathrm{g} / \mathrm{kg})$, pine nuts $(266.33 \mu \mathrm{g} / \mathrm{kg})$, peanuts $(1353.80 \mu \mathrm{g} / \mathrm{kg})$ and pecans $(2689.13 \mu \mathrm{g} / \mathrm{kg}, 2758.26 \mu \mathrm{g} / \mathrm{kg}, 2992.29 \mu \mathrm{g} / \mathrm{kg}$ and $3169.41 \mu \mathrm{g} / \mathrm{kg})$. Extremely high ( $>2500 \mu \mathrm{g} / \mathrm{kg}$ ) Pb content was found in $33 \%$ of studied pecans imported from the USA. The health risk indicators did not identify increased health risk. This research is significant considering the food safety issues and indicates the need to regularly control the content of toxic elements in food, as well as to establish the specific limits for heavy metals content in nuts. The chemometric analysis included cluster analysis and principal component analysis (PCA). Cluster analysis made it possible to distinguish four subgroups on the basis of the ability to accumulate toxic elements: pine nuts, pecans, pistachios and other analysed nuts. PCA indicated primarily factor 1 , distinguishing mainly pecans, macadamia nuts and peanuts. Chemometric analysis can be a useful tool in estimating the ability of different nut species to accumulate contaminants.

Keywords: edible nuts; toxic elements; health risk assessment

\section{Introduction}

Nuts are characterized by high nutritional value and are recommended as a part of a healthy diet. Due to the high content of protein, mono- and polyunsaturated fats (MUFA and PUFA) and fibre as well as vitamins (folates, thiamine, vitamin E), minerals (magnesium, copper) and antioxidants, nuts can consist of a dietary source of these components. Taking into account their high caloric density, nuts intake was considered as a factor which could stimulate weight gain. However, current research does not support this thesis. It was 
demonstrated that nut intake could positively influence changes in metabolic factors such as glycaemic parameters or parameters of lipid metabolism. Moreover, the consumption of nuts was inversely associated with the occurrence of conditions such as hypertension, type 2 diabetes mellitus, obesity and cardiovascular diseases [1]. At the same time, some of the recent studies demonstrated that tree nuts could also be a source of exposure to toxic elements [2-5].

Arsenic (As) is most commonly transferred into the food chain from contaminated water or soil. Moreover, food alongside drinking water is regarded as the main route of human exposure to As [6]. As occurs in three major forms: organic, inorganic, and arsine gas ( -3 oxidative state). Considering valence, there are three major states: As element $(0)$, arsenite $(+\mathrm{III})$ and arsenate $(+\mathrm{V})$. Trivalent $(+\mathrm{III})$ arsenic compounds (both organic and inorganic) are considered more toxic than pentavalent $(+\mathrm{V})$ compounds. Inorganic As is regarded as being more toxic than the organic form [7]. As and inorganic As compounds, due to sufficient evidence, were classified as the first group of carcinogens for humans by the International Agency for Research on Cancer (IARC). It was observed that As exposure enhanced the risk of the occurrence of such cancers as skin, bladder, kidney, liver and lung cancer [8].

Cadmium (Cd) and its compounds, similarly to As, were classified as the first group of carcinogens for humans. Cd exposure is related to the development of several cancersbreast, stomach, kidney, urinary bladder, liver and pancreas. The mechanism involved in cancerogenesis is based on the induction of oxidative stress and irreversible damage to DNA. In non-smoking populations, Cd intake from food is a major source of exposure to this toxic element [8].

Lead $(\mathrm{Pb})$ is the next toxic element which is frequently detected as a contaminant in various foodstuffs. $\mathrm{Pb}$ is highly toxic and could affect almost every organ in the human body. In children, even low levels of $\mathrm{Pb}$ exposure could result in behavioural disruption, learning problems and retarded growth. In adults, $\mathrm{Pb}$ could cause cardiovascular complications and impair the functioning of the kidneys and reproductive system. The IARC categorized $\mathrm{Pb}$ as probably cancerogenic to humans (group 2A) [8].

Mercury $(\mathrm{Hg})$ is present in the environment in three forms: elemental $(\mathrm{Hg})$, organic and inorganic forms. Elemental $\mathrm{Hg}$ is predominant form of $\mathrm{Hg}$ in atmosphere. Organic $\mathrm{Hg}$ is considered as the most toxic and accounts for the vast majority of $\mathrm{Hg}$ exposure. The most frequently detected organic forms are methylmercury $(\mathrm{MeHg})$, and ethylmercury (EtHg). Inorganic forms obtain $\mathrm{Hg}$ salts of $\mathrm{Hg}^{2+}$ and $\mathrm{Hg}_{2}{ }^{2+}$; these compounds are present in disinfectants, fungicides and antiseptics. Each of those forms has different bioavailability and causes different toxic effects in the body. One of the most important causes of human exposure to $\mathrm{Hg}$ (in particular methylmercury) is the consumption of seafood. The critical organ affected by $\mathrm{Hg}$ toxicity is the brain; however, this element is also harmful to the heart, immune system, lungs and kidneys [9].

Long term exposure to even small amounts of toxic elements could be harmful to humans [10]. Diet is regarded as one of the most important sources of these compounds. Thereby, there is a great need to assess the toxicological aspects comprehensively and inform consumers not only about the nutritional aspects of nuts but also about the potential health risks. Due to specific climate conditions in Poland, only hazelnuts and walnuts are cultivated; the remaining nuts available on the market are imported from different parts of the world (North and South America, Africa, Asia and southern Europe). Numerous factors influence the mineral composition of nuts, among others natural environmental factors, climate characteristics, type of soil as well as transport and storage conditions [11]. Heavy metals could migrate to food from the packing materials [12]. Those elements are naturally present in the environment, e.g., as a result of soil erosion. Environmental pollution varies across the continents. In contaminated areas, toxic elements are transferred through the air, water and soil to plants and consequently to the food chain.

The objective of this study was to determine the content of toxic elements (As, Cd, $\mathrm{Pb}$ and $\mathrm{Hg}$ ) in ten of the most popular types of edible nuts and to assess the health risks 
resulting from their consumption. Furthermore, the differences in the content of the studied elements regarding the type of nut as well as the country of origin were determined and discriminated by multivariate analysis.

\section{Materials and Methods}

\subsection{Reagents}

The reagents purchased from the Merck Company (Darmstadt, Germany) were: ultrapure concentrated nitric acid $(69 \%)$, standard solutions of studied elements-arsenic $\left(\mathrm{H}_{3} \mathrm{AsO}_{4}\right.$ in $\left.\mathrm{HNO}_{3} 0.5 \mathrm{~mol} \mathrm{~L}^{-1}, 1000 \mathrm{mg} \mathrm{L}^{-1} \mathrm{As}\right)$, cadmium $\left(\mathrm{Cd}\left(\mathrm{NO}_{3}\right)_{2}\right.$ in $\mathrm{HNO}_{3} 0.5 \mathrm{~mol} \mathrm{~L}{ }^{-1}$, $\left.1000 \mathrm{mg} \mathrm{L}^{-1} \mathrm{Cd}\right)$, lead $\left(\mathrm{Pb}\left(\mathrm{NO}_{3}\right)_{2}\right.$ in $\mathrm{HNO}_{3} 0.5$ mol L$\left.{ }^{-1}, 1000 \mathrm{mg} \mathrm{L}^{-1} \mathrm{~Pb}\right)$, mercury $\left(\mathrm{Hg}\left(\mathrm{NO}_{3}\right)_{2}\right.$ in $\left.\mathrm{HNO}_{3} 2 \mathrm{~mol} \mathrm{~L}^{-1}, 1000 \mathrm{mg} \mathrm{L}^{-1} \mathrm{Hg}\right)$. From Sigma-Aldrich (Saint Louis, $\mathrm{MO}$, USA) ammonium dihydrogen phosphate was obtained. Certified reference material mixed polish herbs (INCT-MPH-2) was obtained from the Institute of Nuclear Chemistry and Technology (Warsaw, Poland).

\subsection{Sample Collection}

The study material consisted of ten types of nuts: Almonds (Prunus dulcis L.), Brazil nuts (Bertholletia excels L.), cashew nuts (Anacardium occidentale L.), hazelnuts (Corylus avellana L.), macadamia nuts (Macadamia ternifolia F.), peanuts (Arachis hypogaea L., which botanically belongs to legume family), pecan nuts (Carya illinoinensis L.), pine nuts (Pinus pinea L.), pistachios (Pistacia vera L.) and walnuts (Juglans regia L.). A total of 120 samples were purchased from markets in standard packages, as well as by weight, between January and March 2021. Ten samples (each of the different producers) were obtained among every studied subgroup without replications. Then, the nuts were transferred into non-sterile polytetrafluoroethylene containers and were stored in a shaded place at room temperature until analyses.

\subsection{Sample Preparation and Digestion}

To obtain a uniform texture of samples for the mineralization process, samples were homogenized using T 18 digital Ultra-Turrax (IKA, Staufen, Germany). Then, an amount of between 200 and $300 \mathrm{mg}$ was weighted to polytetrafluoroethylene vessels and $4 \mathrm{~mL}$ spectrally pure concentrated $(69 \%) \mathrm{HNO}_{3}$ was added (Merck, Darmstadt, Germany). The microwave mineralization was carried out in a close-loop system, applying the procedure described previously (Speedwave, Berghof, Germany) [13]. The digestion procedure consisted of 3 steps. The temperature, pressure, time and power of the microwave generator in the following steps were: $170 / 190 / 210^{\circ} \mathrm{C}, 20 / 30 / 40 \mathrm{~atm}, 10 / 10 / 10 \mathrm{~min}$ and 80/90/90\%, respectively. The final step was to cool the samples at temp. $50{ }^{\circ} \mathrm{C}$, pressure $40 \mathrm{~atm}$, time $18 \mathrm{~min}$ and $0 \%$ of power. The closed digestion system ensures clean sample preparation and no loss of analyte in the case of volatile elements such as As. Digested samples were quantitatively transferred with ultrapure water (Millipore Simplicity UV Water Purification System, Merck, Darmstadt, Germany) to polypropylene vessels and stored at $-20^{\circ} \mathrm{C}$ before determination of $\mathrm{As}, \mathrm{Cd}$ and $\mathrm{Pb}$. After all mass of mineralized samples ranged from $4.264 \mathrm{~g}$ to $6.002 \mathrm{~g}$. Hg content was determined without digestion.

\subsection{Analysis of Toxic Elements Content in Nuts}

\subsubsection{Arsenic}

Inductively coupled plasma-mass spectrometry (ICP-MS, NexION 300D, Perkin Elmer, Waltham, MA, USA) with a kinetic energy discrimination (KED) chamber was used for As measurement. In this configuration, collisions and kinetic energy discriminations are used to correct polyatomic interferences. The conditions on the basis of which the measurements were carried out were: mass $-75 \mathrm{amu}$, dwell time per amu -50 , integration time $-1000 \mathrm{~ms}$, and dual calibration mode. The results were obtained as a count per second and were converted into concentrations based on calibration curves. The limit of As detection (LOD) 
was $0.019 \mu \mathrm{g} / \mathrm{kg}$. For As measurement mineralized samples were diluted 10 times with ultrapure water.

\subsubsection{Cadmium and Lead}

Electrothermal atomic absorption spectrometry analytical technique (ETAAS) with Zeeman background correction for $\mathrm{Cd}$ and $\mathrm{Pb}$ measurement was used (Z-2000, Hitachi, Japan). We used pyrolytically coated graphite cuvettes with widened central section (PyroTube CII HR, Hitachi), particularly suitable for high-sensitivity analyses. The determination of $\mathrm{Cd}$ and $\mathrm{Pb}$ was performed at the wavelengths of $228.8 \mathrm{~nm}$ and $283.3 \mathrm{~nm}$, respectively. We used $0.5 \%$ ammonium dihydrogen phosphate $\left(\mathrm{NH}_{4} \mathrm{H}_{2} \mathrm{PO}_{4}\right.$, Sigma-Aldrich, Saint Louis, $\mathrm{MO}, \mathrm{USA}$ ) as a matrix modifier. The limit of detection value for $\mathrm{Pb}$ and $\mathrm{Cd}$ determination was $1.24 \mu \mathrm{g} / \mathrm{kg}$ and $0.02 \mu \mathrm{g} / \mathrm{kg}$, respectively.

\subsubsection{Mercury}

The atomic absorption spectrometry method (AAS) with the amalgamation technique in a single-purpose atomic absorption spectrometer for $\mathrm{Hg}$ determination was applied (AMA-254, Leco Corp, Altec Ltd., Prague, Czech Republic). Appropriate amounts of samples (about $50 \mathrm{mg}$ with accuracy $0.1 \mathrm{mg}$ ) were placed in the cuvette and analysed. The measurement procedure consists of three steps. First, the samples were burned at $600{ }^{\circ} \mathrm{C}$ in oxygen. Then, the vapours of $\mathrm{Hg}$ passed through the catalytic column to the amalgamator. Additionally, in the last phase after release from the amalgamator, $\mathrm{Hg}$ was measured at a wavelength of $254 \mathrm{~nm}$. The steps lasted $60 \mathrm{~s}, 150 \mathrm{~s}$ and $45 \mathrm{~s}$, respectively. The limit of detection was $0.003 \mathrm{ng} /$ sample.

\subsection{Quality Control of the Analytical Methods Used}

Quality control was carried out prior to the analyses and every 10 samples through analysing certified reference material (mixed Polish herbs (INCT-MPH-2) (Institute of Nuclear Chemistry and Technology, Warsaw, Poland). Obtained results were referred to the standard values provided by the manufacturer. The recovery for $\mathrm{As}, \mathrm{Cd}, \mathrm{Pb}$ and $\mathrm{Hg}$ were: $103 \%, 105 \%, 98.5 \%$, and $102.5 \%$, respectively, while the precision was as follows: $2.1 \%, 2.6 \%, 3.1 \%, 2.9 \%$.

\subsection{Health Risk Assessment}

To assess short and long-term adverse effects (taking into account cancerogenic and non-cancerogenic effects) due to exposure to studied toxic elements following indicators were calculated: estimated daily intake (EDI), cancer risk (CR), target hazard quotient (THQ) and hazard index (HI). Health risk indicators were calculated based on formulas described previously:

$$
\begin{gathered}
\mathrm{EDI}=(\mathrm{C} \times \text { Cons }) \\
\mathrm{CR}=(\mathrm{Fr} \times \mathrm{D} \times \mathrm{EDI} \times \mathrm{Sf}) / \mathrm{T} \times 10^{-3} \\
\mathrm{THQ}=(\mathrm{Fr} \times \mathrm{D} \times \mathrm{Cons} \times \mathrm{C}) /(\mathrm{RfD} \times \mathrm{BW} \times \mathrm{T}) \times 10^{-3} \\
\mathrm{HI}=\sum\left(\mathrm{THQ}_{\mathrm{As}}+\mathrm{THQ}_{\mathrm{Cd}}+\mathrm{THQ}_{\mathrm{Pb}}+\mathrm{THQ}_{\mathrm{Hg}}\right),
\end{gathered}
$$

where $\mathrm{C}$ is the concentration of studied element in sample, Cons is the average level of consumption, Fr is the frequency of exposure (365 days/year), D is the duration of exposure (in this work we have taken the average lifetime of 70 years), Sf is slope factor established by United States Environmental Protection Agency for As- $1.5 \mathrm{mg} / \mathrm{kg} / \mathrm{day}$, for $\mathrm{Cd}-6.3 \mathrm{mg} / \mathrm{kg} /$ day, and for $\mathrm{Pb}-0.0085 \mathrm{mg} / \mathrm{kg} /$ day, $\mathrm{T}$ is the overall time of exposure $(\mathrm{Fr} \times \mathrm{D})$, RfD is oral reference dose for As $0.3 \mu \mathrm{g} / \mathrm{kg} \mathrm{BW/day,} \mathrm{for} \mathrm{Cd}$ and $\mathrm{Pb} 1 \mu \mathrm{g} / \mathrm{kg} \mathrm{BW} /$ day, and for $\mathrm{Hg} 0.3 \mu \mathrm{g} / \mathrm{kg} \mathrm{BW} /$ day and BW is the average body weight [14].

The average daily consumption was estimated at $42 \mathrm{~g}$ [15], while an average body weight of $70 \mathrm{~kg}$ was taken. The European Commission regulations do not specify the norms for $\mathrm{As}, \mathrm{Cd}, \mathrm{Pb}$ and $\mathrm{Hg}$ in nuts, so we used the Polish National Food Safety Standard to 
compare our results with the established levels. The maximum $\mathrm{Cd}$ and $\mathrm{Pb}$ in nuts were founded to be $500 \mu \mathrm{g} / \mathrm{kg}$ and $200 \mu \mathrm{g} / \mathrm{kg}$, respectively, while the levels of As and $\mathrm{Hg}$ in nuts were not included in this regulation [16].

\subsection{Statistical and Multivariate Analysis}

The obtained results were analysed using Statistica 13 software (TIBCO Software Inc., Palo Alto, CA, USA). To assess the normality of data two tests were performedShapiro-Wilk and Kolmogorov-Smirnov. No criterion of the normality was observed, thus, Kruskal-Wallis Analysis of Variance (ANOVA) was used to compare the content of toxic elements among the studied products. Taking into account the country of origin, 81 samples were analysed; the remaining 39 products lacked this information. Most of the nuts were imported from Asia (35), followed by 15 from the North America, 11 from European countries and 11 from Australia, as well as 9 from South America. Significant differences were considered on the levels of $p<0.05, p<0.01$ and $p<0.001$. The results were described as the median and interquartile range (quartile 1-quartile $3, \mathrm{Q}_{1}-\mathrm{Q}_{3}$ ). However, to make comparisons with other authors easier, the mean and minimum-maximum range were also added. A chemometric analysis was also performed, which included cluster analysis, principal components analysis (PCA) and correspondence analysis.

\section{Results and Discussion}

\subsection{Content of Toxic Elements in Nuts}

In our study, the content of toxic elements varied considerably between the types of nut samples (Table 1). We have observed that pecans were generally characterized by a high content of each of the elements studied. All pecan samples were imported from the USA; however, there was no detailed information about the specific area of origin. To the best of our knowledge, there is no research which could explain whether pecans or other nuts accumulate greater amounts of toxic elements. Most probably, the contamination of nuts by toxic elements is the result of environmental pollution [17]. Foodstuffs could also be contaminated with toxic elements through migration from food packages. The levels of contamination vary between selected elements and different packaging materials [18]. Generally, among the studied nuts, we can classify a group of nuts that accumulate toxic elements to a lesser extent, and that group includes almonds, Brazil nuts, cashews, hazelnuts, and walnuts. On the other hand, in the group of nuts which was characterized by increased contents of studied elements were: macadamia nuts, peanuts, pecans, pine nuts and pistachios.

\subsubsection{Arsenic}

In our study, the highest median As content (Table 1) was detected among pistachio nuts $(192.42 \mu \mathrm{g} / \mathrm{kg})$ and the lowest in the subgroup of almonds $(23.59 \mu \mathrm{g} / \mathrm{kg})$. The As levels in the studied material ranged from $13.48 \mu \mathrm{g} / \mathrm{kg}$ in one sample of the cashews to $314.52 \mu \mathrm{g} / \mathrm{kg}$ in the sample of pecans. Those pecans were imported from the USA. The Polish National Food Safety Standard does not determine the maximum levels of As in nuts, therefore, we could not refer our results to any standard. Among the results of the other authors, the highest median As was reported among walnuts $(200 \mu \mathrm{g} / \mathrm{kg}$ - which was four times higher than in this research) as well as results similar to ours in pistachios $(200 \mu \mathrm{g} / \mathrm{kg})$ [19]. According to the literature, the lowest As concentrations were determined to be found in the samples of Brazil nuts [2,20-22]. As its uptake by plants is dependent on its total concentration (considering speciation) in the soil and on the bioavailability, As is most effectively absorbed with protein transporters in inorganic forms-As(III) and As $(V)$. As could alter the morphology and biochemistry and could cause changes at the molecular level, which consequently affect plants' growth and productivity [23]. Among the other foods that could accumulate As in significant amounts, the following products were included: seafood, fruits and vegetables, rice and drinking water. The detected As amounts ranged from 2 to $932 \mu \mathrm{g} / \mathrm{kg}$ [24]. Moreda-Piñeiro et al. in their study, assessed 
the bioavailability of essential and toxic metals in nuts. As content in hazelnuts and pistachios was $78.9 \mu \mathrm{g} / \mathrm{kg}$ and $177 \mu \mathrm{g} / \mathrm{kg}$, while the dialyzable As levels were $59.4 \mu \mathrm{g} / \mathrm{kg}$ and $90.7 \mu \mathrm{g} / \mathrm{kg}$, respectively. That indicates a high percentage of bioavailability of this element from those types of nuts $(75.2 \%$ and $51.1 \%)$. In the remaining study material, the bioavailability was not determined due to the As contents being lower than the LOD $(0.019 \mu \mathrm{g} / \mathrm{kg})[3]$.

\subsubsection{Cadmium}

Considering Cd content, the highest median $(238.40 \mu \mathrm{g} / \mathrm{kg})$ was found for the tested pine nuts (Table 1). On the other hand, the lowest median $(0.54 \mu \mathrm{g} / \mathrm{kg})$ was observed among macadamia nuts, while, in the individual samples, $\mathrm{Cd}$ concentration was between $0.09 \mu \mathrm{g} / \mathrm{kg}$ and $458.22 \mu \mathrm{g} / \mathrm{kg}$ for one sample of macadamia nuts and pine nuts, respectively. The sample of pine nuts with the greatest $\mathrm{Cd}$ content was imported from China. Taking into account the results of other studies, the highest mean Cd level $(695 \mu \mathrm{g} / \mathrm{kg})$ was determined for hazelnuts, and the lowest $(<2 \mu \mathrm{g} / \mathrm{kg})$ for both almonds and walnuts $[4,22]$. In our research, the exceedance of the limit $(500 \mu \mathrm{g} / \mathrm{kg})$ of the Polish National Food Safety Standard (PNFSS) was not observed; however, in eight samples Cd levels were between 200 and $500 \mu \mathrm{g} / \mathrm{kg}$ [16]. Cd is absorbed into plants from the soil and transferred to the fruits. Industrial and urban emissions are listed as being among the main sources of $\mathrm{Cd}$ contamination of the soil. Cd concentrations in food depend on the geographical localization, the bioavailability from the soil, as well as plants' genetics and the fertilizers used [25]. In non-smoking populations, diet is a major source of Cd exposure [26]. The food products which have a higher cadmium accumulation potential are crustaceans, offal (liver, kidneys), nuts, vegetables, coffee, tea and cocoa. The Cd levels in those products ranged from 100 to $4800 \mu \mathrm{g} / \mathrm{kg}$ [27]. It was observed that Cd accumulation in almond seedlings increased with the external concentrations of this toxic element. Moreover, $\mathrm{Cd}$ stress was related to changes in total fatty acids content in all classes [28]. The in vitro bioaccessibility of $\mathrm{Cd}$ from hazelnuts and walnuts was between 26 and $27 \%$ in the gastric juice and between 42 and $45 \%$ in the intestinal juice [29]. However, a lower bioavailability of $\mathrm{Cd}$ in nuts was determined by Moreda-Piñeiro et al. The authors obtained the following results for macadamia nuts $(4.4 \%)$, pecans $(2.2 \%)$, hazelnuts $(3.5 \%)$, peanuts $(2.2 \%)$, pine nuts $(2.3 \%)$ and pistachios $(1.4 \%)$ [3].

\subsubsection{Lead}

The analysis of the $\mathrm{Pb}$ content in the nuts (Table 1) showed that the highest median $(82.06 \mu \mathrm{g} / \mathrm{kg})$ was reached by peanuts, while the highest mean concentration of $\mathrm{Pb}(980.37 \mu \mathrm{g} / \mathrm{kg})$ was found in pecan nuts. The lowest median $(10.95 \mu \mathrm{g} / \mathrm{kg})$ and mean $(13.08 \mu \mathrm{g} / \mathrm{kg})$ concentrations of $\mathrm{Pb}$ were in walnuts. The scatter of $\mathrm{Pb}$ concentration in tested nuts was from $1.71 \mu \mathrm{g} / \mathrm{kg}$ in macadamia to $3169.41 \mu \mathrm{g} / \mathrm{kg}$ in pecans. The sample of pecans found to have the highest $\mathrm{Pb}$ level was imported from the USA. Comparing our findings with the results of other authors, it was found that the Pb content in Brazil nuts, macadamia nuts and pecans was higher than in all the other scientists' analyses [2-4,20,22,30]. In our study, the Pb levels in one sample of peanuts $(1353.80 \mu \mathrm{g} / \mathrm{kg})$, two $(17 \%)$ samples of macadamia nuts $(2350.94$ and $2581.43 \mu \mathrm{g} / \mathrm{kg})$ and four (33\%) of pecans $(2689.13,2758.26,2992.29$ and $3169.41 \mu \mathrm{g} / \mathrm{kg})$ considerably exceeded the Polish National Food Safety Standard established level of $200 \mu \mathrm{g} / \mathrm{kg}$. Besides, two samples-one of macadamia nuts $(221.49 \mu \mathrm{g} / \mathrm{kg})$ as well as one of pine nuts $(266.33 \mu \mathrm{g} / \mathrm{kg})$ - had higher Pb contents than the upper limit [16]. Among the products that could substantially contribute to $\mathrm{Pb}$ exposure are cereal products and grains, vegetables, tea and milk products. The $\mathrm{Pb}$ concentration ranges varied in those products from $0.3 \mu \mathrm{g} / \mathrm{kg}$ to $4300 \mu \mathrm{g} / \mathrm{kg}$ [31].

\subsubsection{Mercury}

During the analysis of $\mathrm{Hg}$ concentration in nut samples (Table 1), it was shown that pecans nuts reached the highest median $(5.77 \mu \mathrm{g} / \mathrm{kg})$ and the highest mean concentra- 
tion $(11.64 \mu \mathrm{g} / \mathrm{kg})$ of $\mathrm{Hg}$. On the other hand, the lowest median $(1.67 \mu \mathrm{g} / \mathrm{kg})$ and the lowest average concentration $(2.40 \mu \mathrm{g} / \mathrm{kg})$ of $\mathrm{Hg}$ were detected in Brazil and macadamia, respectively. The range of the determined values of $\mathrm{Hg}$ concentration in all samples was from $0.23 \mu \mathrm{g} / \mathrm{kg}$ in pine nuts to $44.74 \mu \mathrm{g} / \mathrm{kg}$ in walnuts. Those walnuts were grown in Poland. The results were comparable with those obtained by other authors. The only exceptions were pecan and pine nuts, which showed results different from those published in the literature $[20,32]$. Taking into account the bioaccessibility of toxic elements from nuts, Moreda-Piñeiro et al. found that relatively low amounts of $\mathrm{Hg}$ were dialyzed from hazelnuts. $\mathrm{Hg}$ in raw hazelnuts was $104.6 \mu \mathrm{g} / \mathrm{kg}$, of which $0.96 \mu \mathrm{g} / \mathrm{kg}$ was dialyzed [3]. Among the other foodstuff that contains high amounts of $\mathrm{Hg}$, seafood and fish were found. However, research conducted in recent years has indicated that rice, especially when consumed as a staple food, could also pose a source of exposure [33].

\subsection{Significance Assessment, Correlation and Chemometric Analysis}

Several differences in the content of the studied toxic elements were determined between the subgroups of nuts (Table 2). The $p$-values were put in the superscript.

The correlation coefficient determines the relationship between two parameters and ranges from +1 to -1 . Our analyses showed a strong, negative correlation between the content of $\mathrm{As}$ and $\mathrm{Hg}$ in Brazil nuts $(\mathrm{r}=-0.86, p<0.001)$, between $\mathrm{Pb}$ and $\mathrm{Hg}$ in hazelnuts $(-0.60, p<0.05)$ and in pecan between the content of As and $\mathrm{Cd}(-0.73, p<0.01)$. Moreover, we showed a strong positive correlation between the $\mathrm{Cd}$ and $\mathrm{Pb}$ content in cashews $(\mathrm{r}=0.80$, $p<0.01$ ). Other correlations are presented in Figure 1. These correlations may indicate a tendency to accumulate nuts' individual contaminants-this indicates similar plant uptake rates when using different plant channels.

Cluster analysis aims to group objects in terms of their similarity-in this case, the median content of the examined elements was used. The Euclidean distance was used as a measure of similarity, and clustering was performed by Ward's method. Four main clusters were obtained: the first containing pine nuts, the second-pecan, the third-pistachio, and the fourth-the remaining types of nuts (Figure 2). With reference to the above results, pine nuts had the highest median $\mathrm{Cd}$ content, pecan nuts-the highest $\mathrm{Pb}$ and $\mathrm{Hg}$ content, and pistachio - the highest median As content. Cluster analysis allowed us to distinguish nut species with the highest medians of the tested toxic elements.

PCA is a method which, by transforming the output variables into new variables, builds a model describing the relationships between them. In the case of the content of toxic elements in nuts, a specific model was obtained, because the first component explains as much as $96.55 \%$ of the total variance. According to the Cattell scree plot, only 1 component should be classified for interpretation-in order to create a two-dimensional plot, the first two components were classified, explaining a total of $98.83 \%$ of the variance. The variable $\mathrm{Pb}$ has a coefficient of -0.9997 for the first factor, and the variable $\mathrm{Cd}-0.9993$ for the second factor. Factor 1 distinguishes, among others, pecan nuts, macadamia nuts, and peanuts (Figure 3).

Correspondence analysis allows us to obtain information about the relationships between the categories of variables. When assessing the relationship between the origin and type of nuts, for the first two dimensions, the cumulative percentage of the eigenvalue is $56.17 \%$ (Figure 4 ). 
Table 1. Content of toxic elements in nuts in this study and determined by other authors.

\begin{tabular}{|c|c|c|c|c|c|c|c|c|c|c|c|c|}
\hline \multirow{3}{*}{ Nuts } & \multirow{2}{*}{\multicolumn{2}{|c|}{$\begin{array}{l}\text { As }(\mu \mathrm{g} / \mathrm{kg}) \\
\text { This Study }\end{array}$}} & \multirow{3}{*}{$\begin{array}{c}\text { Other Authors } \\
\qquad \mathbf{X} \pm \mathrm{SD}\end{array}$} & \multirow{2}{*}{\multicolumn{2}{|c|}{$\begin{array}{l}\text { Cd }(\mu \mathrm{g} / \mathrm{kg}) \\
\text { This Study }\end{array}$}} & \multirow{3}{*}{$\begin{array}{c}\text { Other Authors } \\
\qquad \mathbf{X} \pm \mathrm{SD}\end{array}$} & \multirow{2}{*}{\multicolumn{2}{|c|}{$\begin{array}{l}\mathrm{Pb}(\mu \mathrm{g} / \mathrm{kg}) \\
\text { This Study }\end{array}$}} & \multirow{3}{*}{$\begin{array}{c}\text { Other Authors } \\
\mathbf{X} \pm \mathbf{S D}\end{array}$} & \multirow{2}{*}{\multicolumn{2}{|c|}{$\begin{array}{l}\mathrm{Hg}(\mu \mathrm{g} / \mathrm{kg}) \\
\text { This Study }\end{array}$}} & \multirow{3}{*}{$\begin{array}{c}\text { Other Authors } \\
\qquad \mathbf{X} \pm \mathrm{SD}\end{array}$} \\
\hline & & & & & & & & & & & & \\
\hline & $\begin{array}{c}\mathrm{X} \pm \mathrm{SD} \\
\text { Min-Max }\end{array}$ & $\begin{array}{c}\mathrm{Me} \\
\mathrm{Q}_{1}-\mathrm{Q}_{3}\end{array}$ & & $\begin{array}{c}\mathrm{X} \pm \mathrm{SD} \\
\text { Min-Max }\end{array}$ & $\begin{array}{c}\mathrm{Me} \\
\mathrm{Q}_{1}-\mathrm{Q}_{3}\end{array}$ & & $\begin{array}{c}\mathrm{X} \pm \mathrm{SD} \\
\text { Min-Max }\end{array}$ & $\begin{array}{c}\mathrm{Me} \\
\mathrm{Q}_{1}-\mathrm{Q}_{3}\end{array}$ & & $\begin{array}{c}\mathbf{X} \pm \mathrm{SD} \\
\text { Min-Max }\end{array}$ & $\begin{array}{c}\mathrm{Me} \\
\mathrm{Q}_{1}-\mathrm{Q}_{3} \\
\end{array}$ & \\
\hline Almonds & $\begin{array}{c}23.15 \pm 2.34 \\
18.51-26.88\end{array}$ & $\begin{array}{c}23.59 \\
21.84-24.45\end{array}$ & $\begin{array}{c}74.77 \pm 13.04[4] \\
12 \pm 1[3] \\
6.6 \pm 4.0[33]\end{array}$ & $\begin{array}{c}15.75 \pm 12.70 \\
0.89-51.65\end{array}$ & $\begin{array}{l}14.7410 .44- \\
16.47\end{array}$ & $\begin{array}{c}350 \pm 80[22] \\
480 \pm 240[21] \\
36.85 \pm 4.47[4] \\
<2[3]\end{array}$ & $\begin{array}{c}15.06 \pm 10.60 \\
5.21-44.01\end{array}$ & $\begin{array}{c}12.80 \\
8.05-18.53\end{array}$ & $\begin{aligned} 70 & \pm 2[22] \\
281 & \pm 56[21] \\
57.92 & \pm 28.48[4] \\
& <6[3]\end{aligned}$ & $\begin{array}{l}5.84 \pm 6.00 \\
1.45-23.66\end{array}$ & $\begin{array}{c}4.25 \\
3.50-5.04\end{array}$ & $\begin{aligned} 1.4 & \pm 0.3[30] \\
& <7[3] \\
0.72 & \pm 0.45[4] \\
56 & \pm 6[32]\end{aligned}$ \\
\hline Brazil Nuts & $\begin{array}{c}27.12 \pm 8.53 \\
21.17-45.36\end{array}$ & $\begin{array}{c}24.32 \\
22.74-25.17\end{array}$ & $\begin{array}{c}50.34 \pm 2.61[4] \\
9 \pm 1[3] \\
<3[34] \\
1.7 \pm 0.97[4]\end{array}$ & $\begin{array}{c}1.59 \pm 1.43 \\
0.36-5.15\end{array}$ & $\begin{array}{c}1.29 \\
0.44-1.84\end{array}$ & $\begin{array}{c}1.85 \pm 0.25[4] \\
8 \pm 1[3] \\
<5[34] \\
<31[35]\end{array}$ & $\begin{array}{c}82.11 \pm 12.85 \\
63.03-107.02\end{array}$ & $\begin{array}{c}82.47 \\
76.38-88.32\end{array}$ & $\begin{array}{c}12.16 \pm 0.05[4] \\
<6[3] \\
<19.3[36] \\
1.7 \pm 0.97[4]\end{array}$ & $\begin{array}{c}2.97 \pm 3.85 \\
0.97-14.60\end{array}$ & $\begin{array}{c}1.67 \\
1.22-2.33\end{array}$ & $\begin{aligned} & 1.3 \pm 0.4[30] \\
&<7[3] \\
&<2[34] \\
& 0.12 \pm 0.05[4]\end{aligned}$ \\
\hline Cashews & $\begin{array}{c}33.64 \pm 18.31 \\
13.48-71.46\end{array}$ & $\begin{array}{c}26.50 \\
24.77-31.96\end{array}$ & $\begin{array}{c}44.66 \pm 3.46[4] \\
15 \pm 1[3] \\
5.3 \pm 4.7[4] \\
\mathrm{Me}=150[2]\end{array}$ & $\begin{array}{c}13.25 \pm 28.51 \\
1.05-99.14\end{array}$ & $\begin{array}{c}2.46 \\
1.27-5.44\end{array}$ & $\begin{array}{c}400 \pm 210[21] \\
0.99 \pm 0.46[4] \\
12 \pm 1[3] \\
0.8 \pm 0.97[4]\end{array}$ & $\begin{array}{c}20.05 \pm 18.12 \\
2.44-53.99\end{array}$ & $\begin{array}{c}12.06 \\
7.89-30.94\end{array}$ & $\begin{array}{c}661 \pm 68[21] \\
104.5 \pm 19.5[4] \\
<6[3] \\
2.4 \pm 1.4[4]\end{array}$ & $\begin{array}{l}4.54 \pm 3.36 \\
1.12-11.22\end{array}$ & $\begin{array}{c}3.89 \\
1.56-7.26\end{array}$ & $\begin{array}{c}1.6 \pm 0.5[30] \\
<7[22] \\
0.78 \pm 0.46[4] \\
69 \pm 7[32]\end{array}$ \\
\hline Hazelnuts & $\begin{array}{c}29.49 \pm 14.69 \\
21.34-72.17\end{array}$ & $\begin{array}{c}23.96 \\
23.54-26.11\end{array}$ & $\begin{array}{c}78.9 \pm 5.4[37] \\
48.94 \pm 3.37[4] \\
24 \pm 1[3] \\
11 \pm 15[33]\end{array}$ & $\begin{array}{c}11.78 \pm 6.93 \\
3.43-23.22\end{array}$ & $\begin{array}{l}11.00 \\
5.40- \\
16.33\end{array}$ & $\begin{array}{c}695 \pm 27[22] \\
5.5 \pm 0.47[37] \\
58.81 \pm 4.95[4] \\
22 \pm 0.1[3] \\
10 \pm 1.6[4]\end{array}$ & $\begin{array}{c}75.77 \pm 9.42 \\
64.52-94.91\end{array}$ & $\begin{array}{c}74.04 \\
68.66-81.06\end{array}$ & $\begin{array}{c}138 \pm 20[22] \\
99.47 \pm 10.47[4] \\
<6[3] \\
7.3 \pm 8.2[4]\end{array}$ & $\begin{array}{c}4.53 \pm 4.69 \\
1.37-18.38\end{array}$ & $\begin{array}{c}2.77 \\
2.30-4.04\end{array}$ & $\begin{array}{c}104.6 \pm 2.1[37] \\
32 \pm 1[3] \\
2.2 \pm 0.5[4]\end{array}$ \\
\hline $\begin{array}{l}\text { Macadamia } \\
\text { Nuts }\end{array}$ & $\begin{array}{l}38.47 \pm 32.70 \\
19.78-121.29\end{array}$ & $\begin{array}{c}23.49 \\
22.67-30.61\end{array}$ & $\mathrm{Me}=180[2]$ & $\begin{array}{c}0.69 \pm 0.57 \\
0.09-1.87\end{array}$ & $\begin{array}{c}0.54 \\
0.42-0.66\end{array}$ & $\begin{array}{c}481 \pm 15[4] \\
5.2 \pm 0.03[37] \\
460 \pm 230[21] \\
\mathrm{Me}=224[2]\end{array}$ & $\begin{array}{c}437.07 \pm \\
951.00 \\
1.71-2581.43\end{array}$ & $\begin{array}{c}11.44 \\
8.94-67.54\end{array}$ & $\begin{array}{c}84 \pm 8[22] \\
\mathrm{Me}=267[2]\end{array}$ & $\begin{array}{c}2.40 \pm 1.41 \\
1.07-5.47\end{array}$ & $\begin{array}{c}1.92 \\
1.75-2.44\end{array}$ & - \\
\hline Peanuts & $\begin{array}{c}36.07 \pm 18.98 \\
21.10-71.20\end{array}$ & $\begin{array}{c}23.95 \\
22.03-46.14\end{array}$ & $48.49 \pm 4.27[4]$ & $\begin{array}{c}84.49 \pm 69.32 \\
38.58-292.23\end{array}$ & $\begin{array}{l}62.68 \\
48.99- \\
82.19\end{array}$ & $\begin{array}{c}5.5 \pm 0.09[37] \\
520 \pm 190[21] \\
36.84 \pm 3.51[4] \\
\mathrm{Me}=610[2]\end{array}$ & $\begin{array}{c}188.55 \pm \\
367.15 \\
66.76- \\
1353.80\end{array}$ & $\begin{array}{c}82.06 \\
74.55-93.57\end{array}$ & $\begin{array}{c}1862 \pm 225[21] \\
24.30 \pm 3.41[4] \\
\mathrm{Me}=131[2] \\
160[17]\end{array}$ & $\begin{array}{c}2.71 \pm 1.06 \\
1.11-4.57\end{array}$ & $\begin{array}{c}2.46 \\
2.08-3.59\end{array}$ & $\begin{array}{c}2.0 \pm 0.2[30] \\
6[17] \\
119 \pm 14[32]\end{array}$ \\
\hline Pecans & $\begin{array}{c}144.12 \pm \\
106.68 \\
23.60-314.52\end{array}$ & $\begin{array}{l}150.27 \\
39.23- \\
221.08\end{array}$ & $\begin{array}{c}4.5 \pm 1.4[4] \\
150[20]\end{array}$ & $\begin{array}{c}74.50 \pm 35.69 \\
27.11-123.02\end{array}$ & $\begin{array}{c}84.10 \\
33.06- \\
100.72\end{array}$ & $\begin{array}{c}3.5 \pm 0.55[37] \\
45 \pm 26[33] \\
180[20]\end{array}$ & $\begin{array}{c}980.37 \pm \\
1424.09 \\
12.02- \\
3169.41\end{array}$ & $\begin{array}{c}21.23 \\
16.95- \\
2706.41\end{array}$ & $\begin{array}{c}0.82 \pm 0.39[4] \\
5.9[20]\end{array}$ & $\begin{array}{c}11.64 \pm 13.48 \\
2.04-41.72\end{array}$ & $\begin{array}{l}5.77 \\
2.55- \\
14.19\end{array}$ & $2.8 \pm 1.1[4]$ \\
\hline
\end{tabular}


Table 1. Cont.

\begin{tabular}{|c|c|c|c|c|c|c|c|c|c|c|c|c|}
\hline \multirow{3}{*}{ Nuts } & \multirow{2}{*}{\multicolumn{2}{|c|}{$\begin{array}{l}\text { As }(\mu \mathrm{g} / \mathrm{kg}) \\
\text { This Study }\end{array}$}} & \multirow{3}{*}{$\begin{array}{l}\text { Other Authors } \\
\qquad \mathbf{X} \pm \mathrm{SD}\end{array}$} & \multirow{2}{*}{\multicolumn{2}{|c|}{$\begin{array}{l}\mathrm{Cd}(\mu \mathrm{g} / \mathrm{kg}) \\
\text { This Study }\end{array}$}} & \multirow{3}{*}{$\begin{array}{c}\text { Other Authors } \\
\qquad \mathbf{X} \pm \mathrm{SD}\end{array}$} & \multirow{2}{*}{\multicolumn{2}{|c|}{$\begin{array}{l}\mathrm{Pb}(\mu \mathrm{g} / \mathrm{kg}) \\
\text { This Study }\end{array}$}} & \multirow{3}{*}{$\begin{array}{l}\text { Other Authors } \\
\qquad \mathbf{X} \pm \mathrm{SD}\end{array}$} & \multirow{2}{*}{\multicolumn{2}{|c|}{$\begin{array}{l}\mathrm{Hg}(\mu \mathrm{g} / \mathrm{kg}) \\
\text { This Study }\end{array}$}} & \multirow{3}{*}{$\begin{array}{l}\text { Other Author } \\
\qquad \mathbf{X} \pm \text { SD }\end{array}$} \\
\hline & & & & & & & & & & & & \\
\hline & $\begin{array}{c}\mathrm{X} \pm \mathrm{SD} \\
\text { Min-Max }\end{array}$ & $\begin{array}{c}\mathrm{Me} \\
\mathrm{Q}_{1}-\mathrm{Q}_{3}\end{array}$ & & $\begin{array}{c}\mathrm{X} \pm \text { SD } \\
\text { Min-Max }\end{array}$ & $\begin{array}{c}\mathrm{Me} \\
\mathrm{Q}_{1}-\mathrm{Q}_{3} \\
\end{array}$ & & $\begin{array}{c}\mathrm{X} \pm \mathrm{SD} \\
\text { Min-Max }\end{array}$ & $\begin{array}{c}\mathrm{Me} \\
\mathrm{Q}_{1}-\mathrm{Q}_{3} \\
\end{array}$ & & $\begin{array}{c}\mathrm{X} \pm \mathrm{SD} \\
\text { Min-Max }\end{array}$ & $\begin{array}{c}\mathrm{Me} \\
\mathrm{Q}_{1}-\mathrm{Q}_{3} \\
\end{array}$ & \\
\hline $\begin{array}{l}\text { Pine } \\
\text { Nuts }\end{array}$ & $\begin{array}{c}53.78 \pm 37.46 \\
22.13-141.32\end{array}$ & $\begin{array}{c}47.072 \\
2.71-73.77\end{array}$ & $\begin{array}{c}\mathrm{Me}=200[2] \\
160[20]\end{array}$ & $\begin{array}{c}246.87 \pm \\
172.28 \\
35.72-458.22\end{array}$ & $\begin{array}{l}238.40 \\
90.85- \\
408.99\end{array}$ & $\begin{array}{c}5.1 \pm 0.7[37] \\
490 \pm 320[21] \\
\mathrm{Me}=380[2] \\
110[20]\end{array}$ & $\begin{array}{c}48.82 \pm 70.71 \\
11.93-266.33\end{array}$ & $\begin{array}{c}23.73 \\
18.43-39.48\end{array}$ & $\begin{array}{c}730 \pm 250[21] \\
\mathrm{Me}=121[2] \\
21[20]\end{array}$ & $\begin{array}{c}3.97 \pm 1.97 \\
0.23-6.68\end{array}$ & $\begin{array}{c}4.23 \\
3.12-5.19\end{array}$ & $78 \pm 8[32]$ \\
\hline Pistachios & $\begin{array}{c}188.80 \pm \\
54.38 \\
92.84-280.90\end{array}$ & $\begin{array}{l}192.42 \\
153.96- \\
216.20\end{array}$ & $\begin{array}{c}177 \pm 5.3[37] \\
66.56 \pm 0.71[4] \\
\mathrm{Me}=200[2]\end{array}$ & $\begin{array}{l}4.48 \pm 3.88 \\
0.62-13.27\end{array}$ & $\begin{array}{c}2.72 \\
2.09-5.62\end{array}$ & $\begin{array}{c}264 \pm 3[22] \\
3.2 \pm 0.49[37] \\
450 \pm 230[21]\end{array}$ & $\begin{array}{c}21.73 \pm 20.34 \\
3.25-77.88\end{array}$ & $\begin{array}{c}15.80 \\
10.16-27.52\end{array}$ & $\begin{array}{c}42 \pm 4[22] \\
1162 \pm 142[21] \\
20.92 \pm 5.30[4] \\
\mathrm{Me}=118[2]\end{array}$ & $\begin{array}{c}3.82 \pm 2.82 \\
1.31-9.94\end{array}$ & $\begin{array}{c}2.83 \\
2.14-3.76\end{array}$ & $\begin{array}{c}1.8 \pm 0.4[30] \\
32 \pm 4[32]\end{array}$ \\
\hline Walnuts & $\begin{array}{c}41.08 \pm 12.99 \\
19.27-64.57\end{array}$ & $\begin{array}{c}45.19 \\
31.99-46.91\end{array}$ & $\begin{array}{c}64.01 \pm 3.41[4] \\
19 \pm 1[3] \\
7.1 \pm 6.1[4] \\
\mathrm{Me}=200[2]\end{array}$ & $\begin{array}{c}5.48 \pm 10.04 \\
0.15-33.64\end{array}$ & $\begin{array}{c}1.80 \\
0.86-2.54\end{array}$ & $\begin{array}{c}385 \pm 19[22] \\
20 \pm 30[19] \\
490 \pm 320[21]<2 \\
{[3]}\end{array}$ & $\begin{array}{c}13.08 \pm 6.01 \\
5.70-22.26\end{array}$ & $\begin{array}{c}10.95 \\
8.90-18.40\end{array}$ & $\begin{array}{c}64 \pm 3[22] \\
100 \pm 170[19] \\
9.26 \pm 2.19[4] \\
<6[3]\end{array}$ & $\begin{array}{c}7.52 \pm 12.81 \\
0.94-44.74\end{array}$ & $\begin{array}{c}1.94 .65- \\
4.60\end{array}$ & $\begin{array}{c}1.75 \pm 0.9[19] \\
1.8 \pm 0.2[30] \\
15 \pm 1[3] \\
0.8 \pm 0.33[4]\end{array}$ \\
\hline
\end{tabular}

Max—maximum; Me—median; Min—minimum; $\mathrm{Q}_{1}$-lower quartile; $\mathrm{Q}_{3}$-upper quartile; $\mathrm{SD} —$ standard deviation; $\mathrm{X}-$ mean. 
Table 2. Statistically significant differences in the content of the studied elements between tested nuts.

\begin{tabular}{|c|c|c|c|c|c|c|c|c|}
\hline & Almonds & $\begin{array}{l}\text { Brazil } \\
\text { Nuts }\end{array}$ & Cashews & $\begin{array}{l}\text { Macadamia } \\
\text { Nuts }\end{array}$ & Pecans & Pine Nuts & Pistachios & Walnuts \\
\hline Brazil Nuts & $\mathrm{Pb}^{0.001}$ & & $\mathrm{~Pb}^{0.001}$ & $\mathrm{~Pb}^{0.05}$ & $\begin{array}{l}\mathrm{Cd}^{0.001} \\
\mathrm{As}^{0.05} \\
\mathrm{Hg}^{0.05}\end{array}$ & $\mathrm{Cd}^{0.001}$ & $\begin{array}{c}\mathrm{Pb}^{0.001} \\
\mathrm{As}^{0.05}\end{array}$ & $\mathrm{~Pb}^{0.001}$ \\
\hline Cashews & & & & & $\mathrm{Cd}^{0.05}$ & $\mathrm{Cd}^{0.001}$ & $\mathrm{As}^{0.05}$ & \\
\hline Hazelnuts & $\mathrm{Pb}^{0.001}$ & & $\mathrm{~Pb}^{0.001}$ & $\mathrm{Cd}^{0.05}$ & & & $\begin{array}{l}\mathrm{Pb}^{0.05} \\
\mathrm{As}^{0.001}\end{array}$ & $\mathrm{~Pb}^{0.05}$ \\
\hline $\begin{array}{l}\text { Macadamia } \\
\text { Nuts }\end{array}$ & $\mathrm{Cd}^{0.01}$ & & & & $\mathrm{Cd}^{0.001}$ & $\mathrm{Cd}^{0.001}$ & $\mathrm{As}^{0.001}$ & \\
\hline Peanuts & $\mathrm{Pb}^{0.05}$ & $\mathrm{Cd}^{0.001}$ & $\begin{array}{l}\mathrm{Cd}^{0.05} \\
\mathrm{~Pb}^{0.001}\end{array}$ & $\begin{array}{l}\mathrm{Cd}^{0.001} \\
\mathrm{~Pb}^{0.05}\end{array}$ & & & $\begin{array}{l}\mathrm{Cd}^{0.05} \\
\mathrm{~Pb}^{0.001} \\
\mathrm{As}^{0.001}\end{array}$ & $\begin{array}{l}\mathrm{Cd}^{0.001} \\
\mathrm{~Pb}^{0.001}\end{array}$ \\
\hline Pecans & $\mathrm{As}^{0.001}$ & $\mathrm{As}^{0.05}$ & & & & & $\mathrm{Cd}^{0.05}$ & $\mathrm{Cd}^{0.001}$ \\
\hline Pine Nuts & & & & & & & $\mathrm{Cd}^{0.001}$ & $\mathrm{Cd}^{0.001}$ \\
\hline Pistachios & $\mathrm{As}^{0.001}$ & & & & & & & \\
\hline
\end{tabular}

Chemometric analysis, based on the content of selected elements, including As, Cd and $\mathrm{Pb}$, was performed by Kafaoğlu et al. [2]. Our analysis showed a low positive correlation between the content of $\mathrm{Cd}$ and $\mathrm{Pb}$ in all nuts in general $(\mathrm{r}=0.26, p<0.01)$. The cited authors showed a similarly low positive correlation $(r=0.18)$. Moreover, the authors showed a similarity in the content of the elements, despite their different origins. Our analysis allowed us to identify the quality features of the nuts.

\subsection{Health Risk Assessment}

The health risk from intake of the specific species of nuts was calculated based on EDI, THQ, HI and CD indicators. The mean values of health risk indicators of toxic elements from tested nuts, such as EDI, CR, THQ and HI, were presented in Table 3. These indicators are valuable parameters for assessing the health risk of intoxication with the toxic metals associated with the intake of specific nuts. Human consumption of products which exceed the admissible content of toxic elements may have serious health consequences [35]. The lowest EDI, CR and THQ for Cd values were found in smoked macadamia nuts, and they reached $2.91 \times 10^{-5}, 1.83 \times 10^{-7}$ and $4.16 \times 10^{-4}$, respectively. The lowest indicator values were $5.49 \times 10^{-4}, 4.67 \times 10^{-9}$ and $2.24 \times 10^{-34}$ in walnuts for $\mathrm{Pb} ; 9.73 \times 10^{-4}, 1.46 \times 10^{-6}$ and $4.63 \times 10^{-2}$ in almonds for As; $1.01 \times 10^{-4}$ and $4.80 \times 10^{-3}$ in macadamia nuts for $\mathrm{Hg}$, respectively.

The highest EDI, $\mathrm{CR}$ and THQ calculated for $\mathrm{Cd}$ were found in pine nuts $\left(\mathrm{EDI}=1.04 \times 10^{-2}, \mathrm{CR}=6.53 \times 10^{-5}, \mathrm{THQ}=1.48 \times 10^{1}\right)$, for $\mathrm{Pb}$ in pecans $\left(\mathrm{EDI}=4.12 \times 10^{-2}\right.$, $\left.\mathrm{CR}=3.50 \times 10^{-7}, \mathrm{THQ}=1.68 \times 10^{-1}\right)$, for As in pistachio nuts $\left(\mathrm{EDI}=7.93 \times 10^{-3}\right.$, $\left.\mathrm{CR}=1.19 \times 10^{-3}, \mathrm{THQ}=3.78 \times 10^{-1}\right)$ and for $\mathrm{Hg}$ in pecans $\left(\mathrm{EDI}=4.89 \times 10^{-4}\right.$, $\left.\mathrm{CR}=2.33 \times 10^{-2}, \mathrm{THQ}=5.24 \times 10^{-1}\right)$. It has been found that consumption of studied species of nuts does not cause a carcinogenic risk via the content of toxic elements. None of the tested samples exceed the acceptable value of THQ and their consumption is safe for human health. The totality health risk of all toxic elements (HI) found in the samples of selected nuts species was the lowest in almonds $\left(7.00 \times 10^{-2}\right)$ and the highest in pecans $\left(5.24 \times 10^{1}\right)$. The value of $\mathrm{HI}$ is potentially dangerous when it exceeds 1 ; thus, it can be concluded that the consumption of a standard portion of all studied nut species is safe for human health. Summarizing the obtained results of the health risk assessment, it 
was found that the consumption of a standard portion of nuts daily does not pose a threat to human health.
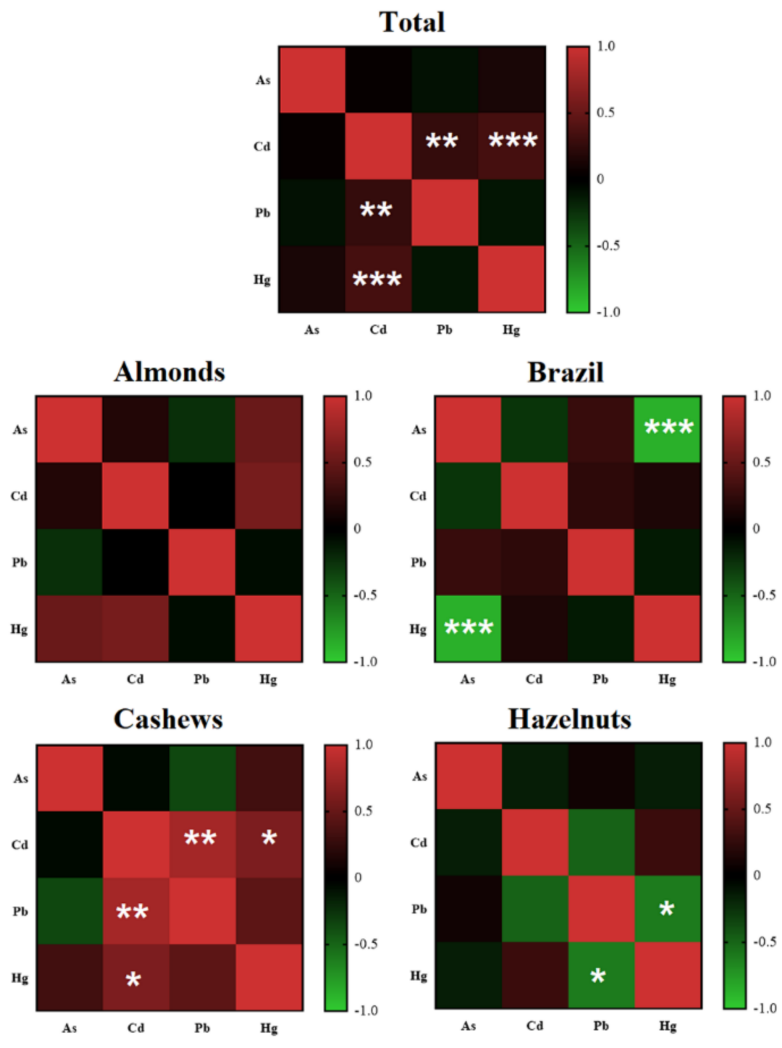

Hazelnuts
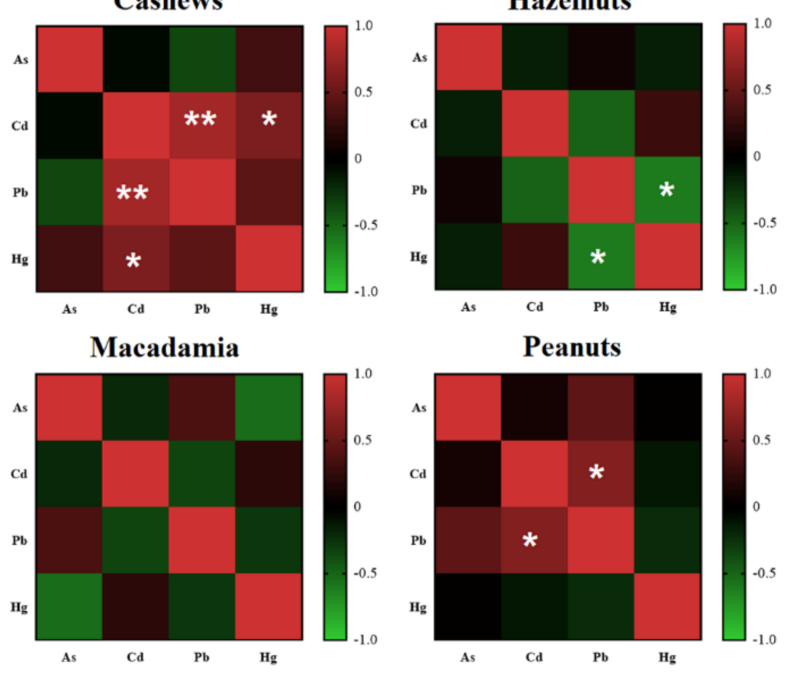

Pecans

Pine
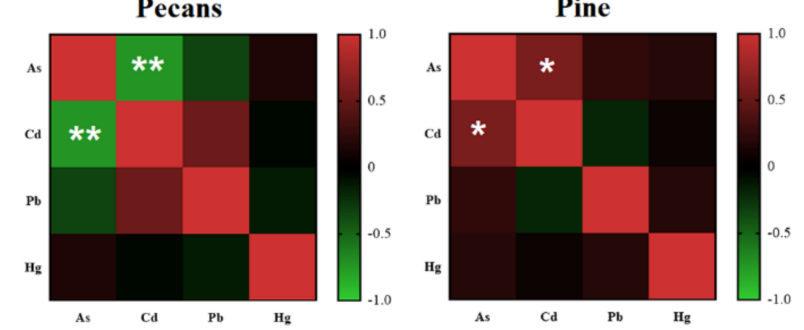

Pistacio

Walnuts
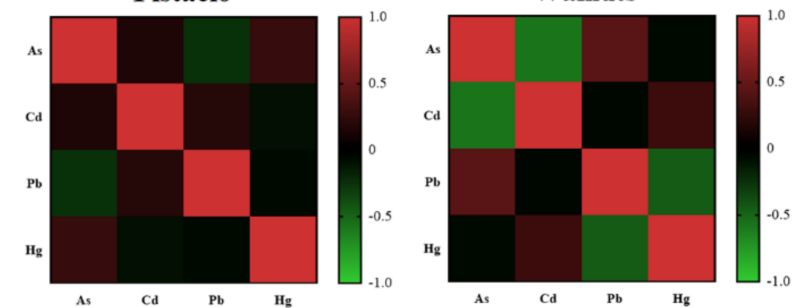

Figure 1. A heatmap of the Spearman correlation between the content of toxic elements. A-almonds; B-Brazil nuts; C—cashews; H-hazelnuts; M-macadamia; Pea-peanuts; Pec-pecans; Pin—pine; Pis-pistachio; W-walnuts, ${ }^{*} p<0.05,{ }^{* *} p<0.01,{ }^{* * *} p<0.001$. 


\section{Cluster analysis}

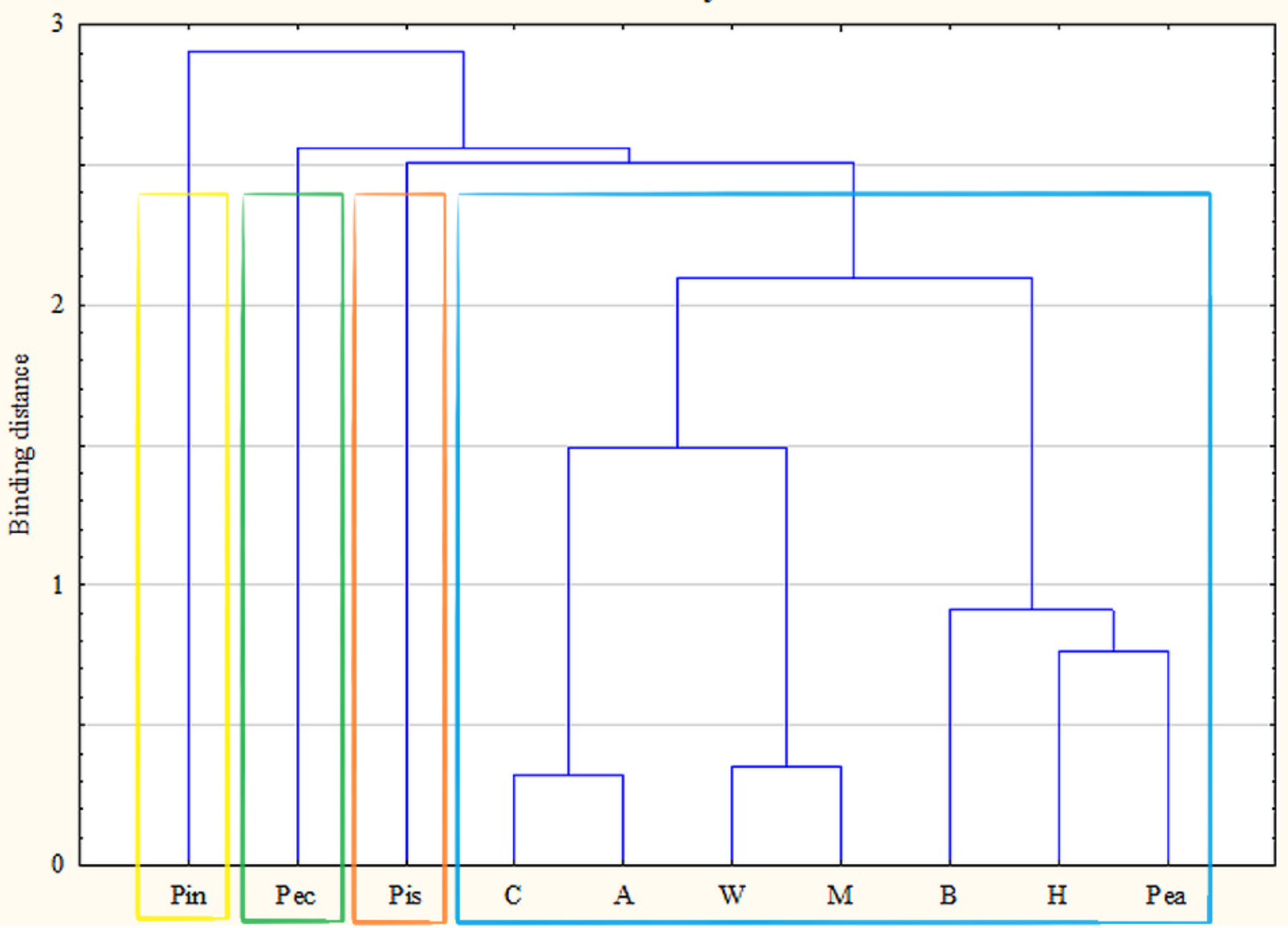

Figure 2. Dendrogram based on the content of toxic elements. A-almonds; B—Brazil nuts; C—cashews; H—hazelnuts; $\mathrm{M}$-macadamia nuts; Pea-peanuts; Pec-pecans; Pin—pine; Pis-pistachios; W—walnuts.

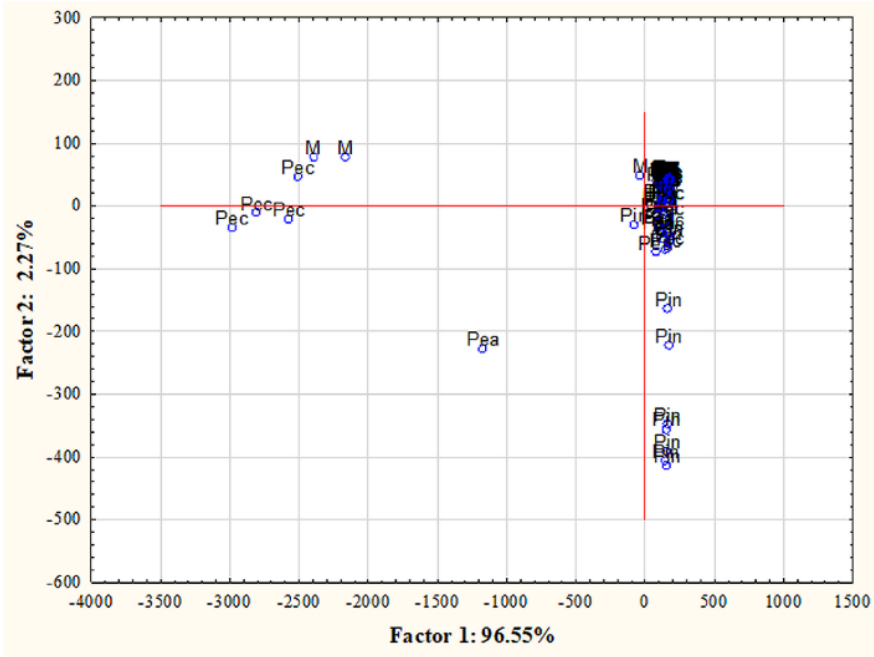

(a)

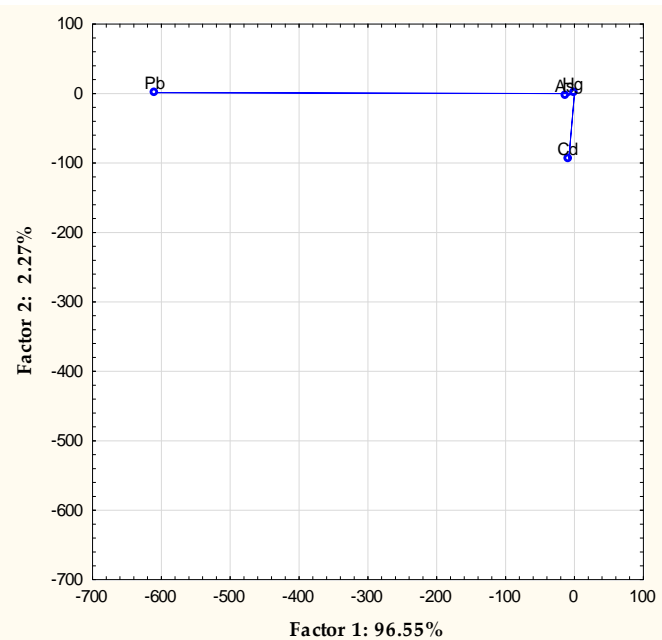

(b)

Figure 3. Two-dimensional plot of factor coordinates for cases (a) and variables (b). A—almonds; B-Brazil nuts; C—cashews; H—hazelnuts; M-macadamia; Pea—peanuts; Pec—pecans; Pin—pine; Pis—pistachio; W—walnuts. 


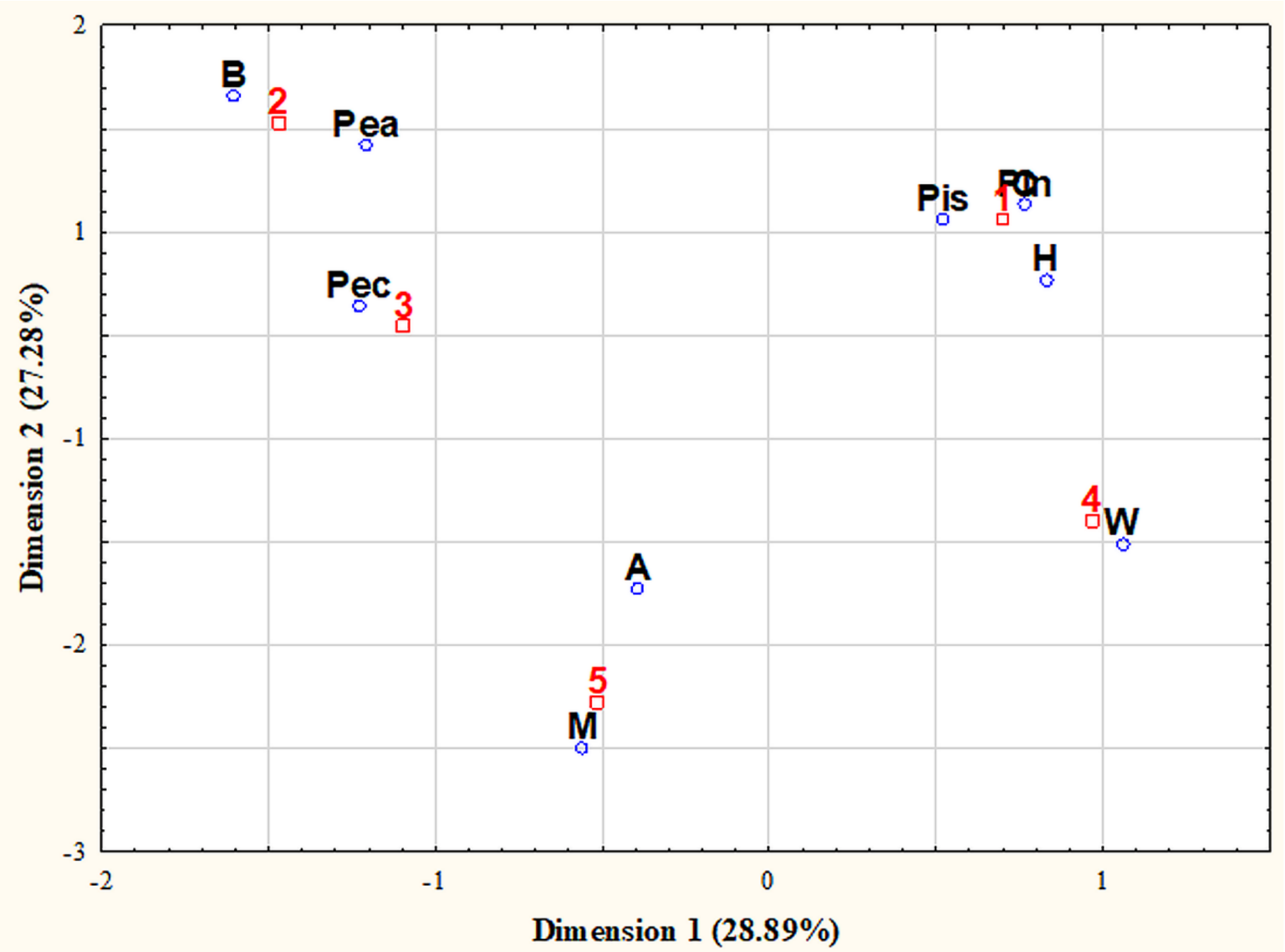

Figure 4. Two-dimensional graph for the tested nuts. A-almonds; B-Brazil nuts; C—cashews; H-hazelnuts; Mmacadamia; Pea-peanuts; Pec-pecans; Pin-pine; Pis—pistachios; W-walnuts; 1-Asia; 2-South America; 3-North America; 4-Europe; 5-Australia.

After a detailed analysis of the available literature, it was shown that the current knowledge was lacking information about the assessment of health risks resulting from the consumption of portions of nuts contaminated with toxic elements. Currently, only publications on the health risk assessments of walnuts and pistachios were available. In the case of walnuts, the THQ values obtained in the research for $\mathrm{Cd}, \mathrm{Pb}$ and As were lower than those obtained by other authors (Cd: $1.00 \times 10^{-1}, \mathrm{~Pb}: 9.00 \times 10^{-2}$ and As: $2.00 \times 10^{-2}$ ). On the other hand, the THQ value for $\mathrm{Hg}$ in the tested walnuts was higher than the results available in the literature $\left(\mathrm{Hg}: 8.00 \times 10^{-2}\right)$ [38]. Taghizadeh et al. determined risk of endpoints posed through exposure to toxic elements, such as $\mathrm{As}$ and $\mathrm{Pb}$, via the consumption of walnuts from Iran in the general population. Based on his research, the THQ calculated for As were $2.30 \times 10^{-1}$ and $0.04 \times 10^{1}$ for the 50th and 95th centiles and for $\mathrm{Pb}$ was $1.03 \times 10^{-3}$ and $2.01 \times 10^{-3}$ for the 50th and 95th centiles, respectively. The CR value of walnuts for As and $\mathrm{Pb}$ reached $1.03 \times 10^{-4}$ and $3.11 \times 10^{-4}$ for As and $4.71 \times 10^{-9}$ and $1.05 \times 10^{-8}$ for $\mathrm{Pb}$ for the 50th and 95th centiles, respectively [39]. The health risk assessment of exposure to $\mathrm{As}, \mathrm{Cd}$ and $\mathrm{Pb}$ after intake of walnuts was also examined by $\mathrm{Wu}$ et al. and reached values of $0.02 \times 10^{0}, 0.07 \times 10^{-1}$ and $0.01 \times 10^{0}$, respectively. These walnuts cultivated in China reached THQ values higher than the results obtained in our research [40]. Pistachios were another species of nuts whose health risk assessment was carried out. The health risk assessment resulting from the As content in the nuts showed that the THQ value of the tested pistachios was higher than the value of Iranian pistachios, available in published scientific studies (As-4.50 $\times 10^{-2}$ ). The $\mathrm{HI}$ calculated in our research was lower than the value determined by Taghizadeh et al. $\left(\mathrm{HI}-4.68 \times 10^{-1}\right)$ [39]. 
Table 3. Estimated human health risk calculated for toxic elements ( $\mathrm{Hg}, \mathrm{Pb}, \mathrm{Cd}$ and $\mathrm{As})$ through consumption of selected species of nuts.

\begin{tabular}{|c|c|c|c|c|c|c|c|c|c|c|c|c|}
\hline \multirow[b]{2}{*}{ Nuts } & \multicolumn{3}{|c|}{ As } & \multicolumn{3}{|c|}{$\mathrm{Cd}$} & \multicolumn{3}{|c|}{$\mathrm{Pb}$} & \multicolumn{2}{|c|}{$\mathrm{Hg}$} & \multirow[b]{2}{*}{ HI } \\
\hline & $\begin{array}{c}\text { EDI } \\
\text { (mg/Day) }\end{array}$ & CR & THQ & $\begin{array}{c}\text { EDI } \\
\text { (mg/Day) }\end{array}$ & CR & THQ & $\begin{array}{c}\text { EDI } \\
\text { (mg/Day) }\end{array}$ & CR & THQ & $\begin{array}{c}\text { EDI } \\
\text { (mg/Day) }\end{array}$ & THQ & \\
\hline Almonds & $\begin{array}{c}9.73 \times 10^{-4} \\
\pm 9.82 \times \\
10^{-5} \\
(7.77 \times \\
10^{-4}-1.13 \times \\
\left.10^{-3}\right)\end{array}$ & $\begin{array}{c}1.46 \times 10^{-6} \\
\pm 1.47 \times \\
10^{-7} \\
(1.17 \times \\
10^{-6}-1.69 \times \\
\left.10^{-6}\right)\end{array}$ & $\begin{array}{c}4.63 \times 10^{-2} \\
\pm 4.68 \times \\
10^{-3} \\
(3.70 \times \\
10^{-2}-5.38 \times \\
\left.10^{-2}\right)\end{array}$ & $\begin{array}{c}6.61 \times 10^{-4} \\
\pm 5.33 \times \\
10^{-4} \\
(3.72 \times \\
10^{-5}-2.17 \times \\
\left.10^{-3}\right)\end{array}$ & $\begin{array}{c}4.17 \times 10^{-6} \\
\pm 3.36 \times \\
10^{-6} \\
(2.34 \times \\
10^{-7}-1.37 \times \\
\left.10^{-5}\right)\end{array}$ & $\begin{array}{c}9.45 \times 10^{-3} \\
\pm 7.62 \times \\
10^{-3} \\
(5.31 \times \\
10^{-4}-3.10 \times \\
\left.10^{-2}\right)\end{array}$ & $\begin{array}{c}6.32 \times 10^{-4} \\
\pm 4.45 \times \\
10^{-4} \\
(2.19 \times \\
10^{-4}-1.85 \times \\
\left.10^{-3}\right)\end{array}$ & $\begin{array}{c}5.38 \times 10^{-9} \\
\pm 3.78 \times \\
10^{-9} \\
(1.86 \times \\
10^{-9}-1.57 \times \\
\left.10^{-8}\right)\end{array}$ & $\begin{array}{c}2.58 \times 10^{-3} \\
\pm 1.82 \times \\
10^{-3} \\
(8.92 \times \\
10^{-4}-7.54 \times \\
\left.10^{-3}\right)\end{array}$ & $\begin{array}{c}2.45 \times 10^{-4} \\
\pm 2.52 \times \\
10^{-4} \\
(6.11 \times \\
10^{-5}-9.94 \times \\
\left.10^{-4}\right)\end{array}$ & $\begin{array}{c}1.17 \times 10^{-2} \\
\pm 1.20 \times \\
10^{-2} \\
(2.91 \times \\
10^{-3}-4.73 \times \\
\left.10^{-2}\right)\end{array}$ & $\begin{array}{c}7.00 \times 10^{-2} \\
\pm 1.82 \times \\
10^{-2} \\
(5.50 \times \\
10^{-2}-1.15 \times \\
\left.10^{-1}\right)\end{array}$ \\
\hline Cashews & $\begin{array}{c}1.41 \times 10^{-3} \\
\pm 7.69 \times \\
10^{-4} \\
(5.66 \times \\
10^{-4}-3.00 \times \\
\left.10^{-3}\right)\end{array}$ & $\begin{array}{c}2.12 \times 10^{-6} \\
\pm 1.15 \times \\
10^{-6} \\
(8.49 \times \\
10^{-7}-4.50 \times \\
\left.10^{-6}\right)\end{array}$ & $\begin{array}{c}6.73 \times 10^{-2} \\
\pm 3.66 \times \\
10^{-2} \\
(2.70 \times \\
10^{-2}-1.43 \times \\
\left.10^{-1}\right)\end{array}$ & $\begin{array}{c}5.57 \times 10^{-4} \\
\pm 1.20 \times \\
10^{-3} \\
(4.41 \times \\
10^{-5}-4.16 \times \\
\left.10^{-3}\right)\end{array}$ & $\begin{array}{c}3.51 \times 10^{-6} \\
\pm 7.54 \times \\
10^{-6} \\
(2.78 \times \\
10^{-7}-2.62 \times \\
\left.10^{-5}\right)\end{array}$ & $\begin{array}{c}7.95 \times 10^{-3} \\
\pm 1.71 \times \\
10^{-2} \\
(6.30 \times \\
10^{-4}-5.95 \times \\
\left.10^{-2}\right)\end{array}$ & $\begin{array}{c}8.42 \times 10^{-4} \\
\pm 7.61 \times \\
10^{-4} \\
(1.03 \times \\
10^{-4}-2.27 \times \\
\left.10^{-3}\right)\end{array}$ & $\begin{array}{c}7.16 \times 10^{-9} \\
\pm 6.47 \times \\
10^{-9} \\
(8.72 \times \\
10^{-10}-1.93 \times \\
\left.10^{-8}\right)\end{array}$ & $\begin{array}{c}3.44 \times 10^{-3} \\
\pm 3.11 \times \\
10^{-3} \\
(4.19 \times \\
10^{-4}-9.26 \times \\
\left.10^{-3}\right)\end{array}$ & $\begin{array}{c}1.91 \times 10^{-4} \\
\pm 1.41 \times \\
10^{-4} \\
(4.68 \times \\
10^{-5}-4.71 \times \\
\left.10^{-4}\right)\end{array}$ & $\begin{array}{c}9.08 \times 10^{-3} \\
\pm 6.72 \times \\
10^{-3} \\
(2.23 \times \\
10^{-3}-2.24 \times \\
\left.10^{-2}\right)\end{array}$ & $\begin{array}{c}8.77 \times 10^{-2} \\
\pm 4.32 \times \\
10^{-2} \\
(5.16 \times \\
10^{-2}-1.64 \times \\
\left.10^{-1}\right)\end{array}$ \\
\hline Hazelnuts & $\begin{array}{c}1.24 \times 10^{-3} \\
\pm 6.17 \times \\
10^{-4} \\
(8.96 \times \\
10^{-4}-3.03 \times \\
\left.10^{-3}\right)\end{array}$ & $\begin{array}{c}1.86 \times 10^{-6} \\
\pm 9.25 \times \\
10^{-7} \\
(1.34 \times \\
10^{-6}-4.55 \times \\
\left.10^{-6}\right)\end{array}$ & $\begin{array}{c}5.90 \times 10^{-2} \\
\pm 2.94 \times \\
10^{-2} \\
(4.27 \times \\
10^{-2}-1.44 \times \\
\left.10^{-1}\right)\end{array}$ & $\begin{array}{c}4.95 \times 10^{-4} \\
\pm 2.91 \times \\
10^{-4} \\
(1.44 \times \\
10^{-4}-9.75 \times \\
\left.10^{-4}\right)\end{array}$ & $\begin{array}{c}3.12 \times 10^{-6} \\
\pm 1.83 \times \\
10^{-6} \\
(9.08 \times \\
10^{-7}-6.14 \times \\
\left.10^{-6}\right)\end{array}$ & $\begin{array}{c}7.07 \times 10^{-3} \\
\pm 4.16 \times \\
10^{-3} \\
(2.06 \times \\
10^{-3}-1.39 \times \\
\left.10^{-2}\right)\end{array}$ & $\begin{array}{c}3.18 \times 10^{-3} \pm \\
3.96 \times 10^{-4} \\
(2.71 \times \\
10^{-3}-3.99 \times \\
\left.10^{-3}\right)\end{array}$ & $\begin{array}{c}2.70 \times 10^{-8} \\
\pm 3.36 \times \\
10^{-9} \\
(2.30 \times \\
10^{-8}-3.39 \times \\
\left.10^{-8}\right)\end{array}$ & $\begin{array}{c}1.30 \times 10^{-2} \\
\pm 1.61 \times \\
10^{-3} \\
(1.11 \times \\
10^{-2}-1.63 \times \\
\left.10^{-2}\right)\end{array}$ & $\begin{array}{c}1.90 \times 10^{-4} \\
\pm 1.97 \times \\
10^{-4} \\
(5.74 \times \\
10^{-5}-7.72 \times \\
\left.10^{-4}\right)\end{array}$ & $\begin{array}{c}9.05 \times 10^{-3} \\
\pm 9.37 \times \\
10^{-3} \\
(2.73 \times \\
10^{-3}-3.68 \times \\
\left.10^{-2}\right)\end{array}$ & $\begin{array}{c}8.81 \times 10^{-2} \\
\pm 2.88 \times \\
10^{-2} \\
(6.62 \times \\
10^{-2}-1.64 \times \\
\left.10^{-1}\right)\end{array}$ \\
\hline $\begin{array}{l}\text { Macadamia } \\
\text { Nuts }\end{array}$ & $\begin{array}{c}1.62 \times 10^{-3} \\
\pm 1.37 \times \\
10^{-3} \\
(8.31 \times \\
10^{-4}-5.09 \times \\
\left.10^{-3}\right)\end{array}$ & $\begin{array}{c}2.42 \times 10^{-6} \\
\pm 2.06 \times \\
10^{-6} \\
(1.25 \times \\
10^{-6}-7.64 \times \\
\left.10^{-6}\right)\end{array}$ & $\begin{array}{c}7.69 \times 10^{-2} \\
\pm 6.54 \times \\
10^{-2} \\
(3.96 \times \\
10^{-2}-2.43 \times \\
\left.10^{-1}\right)\end{array}$ & $\begin{array}{c}2.91 \times 10^{-5} \\
\pm 2.40 \times \\
10^{-5} \\
(3.86 \times \\
10^{-6}-7.85 \times \\
\left.10^{-5}\right)\end{array}$ & $\begin{array}{c}1.83 \times 10^{-7} \\
\pm 1.51 \times \\
10^{-7} \\
(2.43 \times \\
10^{-8}-4.94 \times \\
\left.10^{-7}\right)\end{array}$ & $\begin{array}{c}4.16 \times 10^{-4} \\
\pm 3.42 \times \\
10^{-4} \\
(5.52 \times \\
10^{-5}-1.12 \times \\
\left.10^{-3}\right)\end{array}$ & $\begin{array}{c}1.84 \times 10^{-2} \\
\pm 3.99 \times \\
10^{-2} \\
(7.19 \times \\
10^{-5}-1.08 \times \\
\left.10^{-1}\right)\end{array}$ & $\begin{array}{c}1.56 \times 10^{-7} \\
\pm 3.40 \times \\
10^{-7} \\
(6.11 \times \\
10^{-10-9.22 \times} \\
\left.10^{-7}\right) \\
\end{array}$ & $\begin{array}{c}7.49 \times 10^{-2} \\
\pm 1.63 \times \\
10^{-1} \\
(2.93 \times \\
10^{-4}-4.43 \times \\
\left.10^{-1}\right)\end{array}$ & $\begin{array}{c}1.01 \times 10^{-4} \\
\pm 5.91 \times \\
10^{-5} \\
(4.48 \times \\
10^{-5}-2.30 \times \\
\left.10^{-4}\right)\end{array}$ & $\begin{array}{c}4.80 \times 10^{-3} \\
\pm 2.81 \times \\
10^{-3} \\
(2.13 \times \\
10^{-3}-1.09 \times \\
\left.10^{-2}\right)\end{array}$ & $\begin{array}{c}1.57 \times 10^{-1} \\
\pm 2.03 \times \\
10^{-1} \\
(4.72 \times \\
10^{-2}-6.89 \times \\
\left.10^{-1}\right)\end{array}$ \\
\hline Peanuts & $\begin{array}{c}1.51 \times 10^{-3} \\
\pm 7.97 \times \\
10^{-4} \\
(8.86 \times \\
10^{-4}-2.99 \times \\
\left.10^{-3}\right)\end{array}$ & $\begin{array}{c}2.27 \times 10^{-6} \\
\pm 1.20 \times \\
10^{-6} \\
(1.33 \times \\
10^{-6}-4.49 \times \\
\left.10^{-6}\right)\end{array}$ & $\begin{array}{c}7.21 \times 10^{-2} \\
\pm 3.80 \times \\
10^{-2} \\
(4.22 \times \\
10^{-2}-1.42 \times \\
\left.10^{-1}\right)\end{array}$ & $\begin{array}{c}3.55 \times 10^{-3} \\
\pm 2.91 \times \\
10^{-3} \\
(1.62 \times \\
10^{-3}-1.23 \times \\
\left.10^{-2}\right)\end{array}$ & $\begin{array}{c}2.24 \times 10^{-5} \\
\pm 1.83 \times \\
10^{-5} \\
(1.02 \times \\
10^{-5}-7.73 \times \\
\left.10^{-5}\right)\end{array}$ & $\begin{array}{c}5.07 \times 10^{-2} \\
\pm 4.16 \times \\
10^{-2} \\
(2.31 \times \\
10^{-2}-1.75 \times \\
\left.10^{-1}\right)\end{array}$ & $\begin{array}{c}7.92 \times 10^{-3} \\
\pm 1.54 \times \\
10^{-2} \\
(2.80 \times \\
10^{-3}-5.69 \times \\
\left.10^{-2}\right)\end{array}$ & $\begin{array}{c}6.73 \times 10^{-8} \\
\pm 1.31 \times \\
10^{-7} \\
(2.38 \times \\
10^{-8}-4.83 \times \\
\left.10^{-7}\right)\end{array}$ & $\begin{array}{c}3.23 \times 10^{-2} \\
\pm 6.29 \times \\
10^{-2} \\
(1.14 \times \\
10^{-2}-2.32 \times \\
\left.10^{-1}\right)\end{array}$ & $\begin{array}{c}1.14 \times 10^{-4} \\
\pm 4.45 \times \\
10^{-5} \\
(4.66 \times \\
10^{-5}-1.92 \times \\
\left.10^{-4}\right)\end{array}$ & $\begin{array}{c}5.43 \times 10^{-3} \\
\pm 2.12 \times \\
10^{-3} \\
(2.22 \times \\
10^{-3}-9.14 \times \\
\left.10^{-3}\right)\end{array}$ & $\begin{array}{c}1.61 \times 10^{-1} \\
\pm 1.03 \times \\
10^{-1} \\
(8.75 \times \\
10^{-2}-4.60 \times \\
\left.10^{-1}\right)\end{array}$ \\
\hline
\end{tabular}


Table 3. Cont.

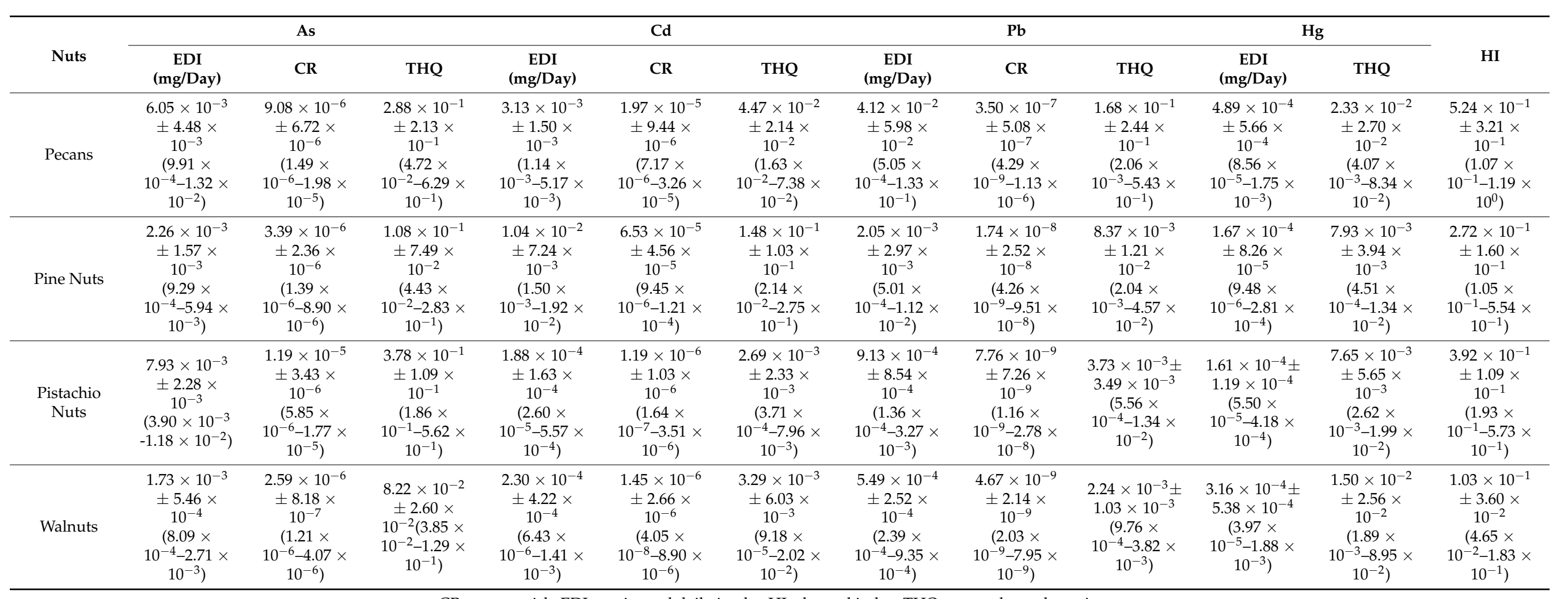

CR—cancer risk; EDI—estimated daily intake; HI—hazard index; THQ—-target hazard quotient. 


\section{Conclusions}

In our study, the content of toxic elements varied considerably between types of nut samples, which was confirmed by chemometric analysis. To our knowledge, this is the first study that comprehensively evaluated the health risks due to the consumption of nuts among the Polish population. The exceedance of the established limit of $\mathrm{Pb}$ was found in nine samples $(7.5 \%)$, while $33 \%$ of tested pecans had extremely high (over $2500 \mu \mathrm{g} / \mathrm{kg}$ ) $\mathrm{Pb}$ levels. However, the other tested products seem to be safe to consume. Not only the content of the toxic elements in food products, but also the level of their consumption plays a crucial role in evaluating the health risk. Furthermore, we see a great need to establish the maximum levels of toxic elements in nuts in the official European regulations. Foods available on the market should be controlled regularly, since food safety and quality are included in the most important public health issues.

Author Contributions: Conceptualization, J.B., A.P.-J., R.M.-Ż. and K.S.; methodology, J.B., A.P.-J., R.M.-Ż., J.S., K.P., K.K. and K.S.; software, J.B., A.P.-J., P.N., M.G. and K.M.; validation, R.M.-Ż. and K.S.; formal analysis, R.M.-Ż. and K.S.; investigation, K.S.; resources, A.P.-J., R.M.-Ż., J.S. and K.S.; data curation, J.B., A.P.-J., P.N., M.G. and K.M.; writing-original draft preparation, J.B. and A.P.-J. writing—review and editing, K.S.; visualization, A.P.-J., P.N., M.G. and K.M.; supervision, R.M.-Ż and K.S.; project administration, R.M.-Ż. and K.S.; funding acquisition, K.S. All authors have read and agreed to the published version of the manuscript.

Funding: This research was funded by the Medical University of Białystok, grant number N/ST/ZB/17/001/2216 and SUB/3/DN/21/001/2216.

Institutional Review Board Statement: Not applicable.

Informed Consent Statement: Not applicable.

Data Availability Statement: Data are available from the authors.

Conflicts of Interest: The authors declare no conflict of interest.

\section{References}

1. De Souza, R.G.M.; Schincaglia, R.M.; Pimentel, G.D.; Mota, J.F. Nuts and human health outcomes: A systematic review. Nutrients 2017, 9, 1311. [CrossRef]

2. Kafaoğlu, B.; Fisher, A.; Hill, S.; Kara, D. Chemometric evaluation of trace metal concentrations in some nuts and seeds. Food Addit. Contam. Part A 2014, 31, 1529-1538. [CrossRef]

3. Moreda-Piñeiro, J.; Sánchez-Piñero, J.; Alonso-Rodríguez, E.; Turnes-Carou, I.; López-Mahía, P.; Muniategui-Lorenzo, S. Major, minor and trace elements composition of Amazonian foodstuffs and its contribution to dietary intake. J. Food Meas. Charact. 2020, 14, 1314-1324. [CrossRef]

4. Bašić, M.; Beganović, L.; Huremović, J.; Žero, S. Assessment of metals and their estimated daily intakes in various nuts. Agric. For. 2020, 66, 211-219. [CrossRef]

5. Harangozo, L'.; Šnirc, M.; Árvay, J.; Jakabová, S.; Čéryová, S. Biogenic and risk elements in walnuts (Juglans regia L.) from chosen localities of Slovakia. Biol. Trace Elem. Res. 2021, 199, 2047-2056. [CrossRef] [PubMed]

6. EFSA. Panel on contaminants in the food chain (CONTAM), Scientific opinion on arsenic in food. EFSA J. 2009, 7, 1351. [CrossRef]

7. Kuivenhoven, M.; Mason, K. Arsenic Toxicity; StatPearls Publishing: Treasure Island, FL, USA, 2021.

8. International Agency for Research on Cancer. IARC Monographs on the Evaluation of Carcinogenic Risks to Humans; IARC: Lyon, France, 2020.

9. EFSA. EFSA Panel on contaminants in the food chain (CONTAM), Scientific opinion on the risk for public health related to the presence of mercury and methylmercury in food. EFSA J. 2012, 10, 2985.

10. Lanre-Iyanda, T.Y.; Adekunle, I.M. Assessment of heavy metals and their estimated daily intakes from two commonly consumed foods (kulikuli and robo) found in Nigeria. Afr. J. Food Agric. Nutr. Dev. 2012, 12, 6156.

11. Santos, E.; Lauria, D.; da Silveira, C.P. Assessment of daily intake of trace elements due to consumption of foodstuffs by adult inhabitants of Rio de Janeiro city. Sci. Total Environ. 2004, 327, 69-79. [CrossRef]

12. Li, C.; Li, C.; Yu, H.; Cheng, Y.; Xie, Y.; Yao, W.; Guo, Y.; Qian, H. Chemical food contaminants during food processing: Sources and control. Crit. Rev. Food Sci. Nutr. 2021, 61, 1545-1555. [CrossRef]

13. Bielecka, J.; Markiewicz-Żukowska, R.; Nowakowski, P.; Grabia, M.; Puścion-Jakubik, A.; Mielcarek, K.; Gromkowska-Kępka, K.J.; Soroczyńska, J.; Socha, K. Content of Toxic Elements in 12 Groups of Rice Products Available on Polish Market: Human Health Risk Assessment. Foods 2020, 9, 1906. [CrossRef] 
14. Nowakowski, P.; Markiewicz-Żukowska, R.; Soroczyńska, J.; Puścion-Jakubik, A.; Mielcarek, K.; Borawska, M.H.; Socha, K. Evaluation of toxic element content and health risk assessment of edible wild mushrooms. J. Food Compos. Anal. 2021, $96,103698$. [CrossRef]

15. Berryman, C.E.; West, S.G.; Fleming, J.A.; Bordi, P.L.; Kris-Etherton, P. Effects of daily almond consumption on cardiometabolic risk and abdominal adiposity in healthy adults with elevated LDL-cholesterol: A randomized controlled trial. J. Am. Heart Assoc. 2015, 4, e000993. [CrossRef] [PubMed]

16. Polish National Food Safety Standard, Maximum Contamination Levels in Foodstuffs. National Commission for Health and Family Planning (GB 2762-2012)—General Veterinary Inspectorate. Available online: https:/ /www.wetgiw.gov.pl/main/szukaj? szukaj=maksymalne+poziomy+zanieczyszcze $\%$ C5\%84 (accessed on 20 August 2021).

17. Gu, Q.; Yu, T.; Yang, Z.; Ji, J.; Hou, Q.; Wang, L.; Wei, X.; Zhang, Q. Prediction and risk assessment of five heavy metals in maize and peanut: A case study of Guangxi, China. Environ. Toxicol. Pharmacol. 2019, 70, 103199. [CrossRef] [PubMed]

18. Duran, A.; Tuzen, M.; Soylak, M. Evaluation of metal concentrations in food packaging materials: Relation to human health. At. Spectrosc. 2013, 34, 99-103. [CrossRef]

19. Łoźna, K.; Styczyńska, M.; Biernat, J.; Hyla, J.; Bienkiewicz, M.; Figurska-Ciura, D.; Bronkowska, M. Mineral composition of tree nuts and seeds. J. Elem. 2020, 25, 745-756. [CrossRef]

20. Rodushkin, I.; Engström, E.; Sörlin, D.; Baxter, D. Levels of inorganic constituents in raw nuts and seeds on the Swedish market. Sci. Total. Environ. 2008, 392, 290-304. [CrossRef] [PubMed]

21. Welna, M.; Klimpel, M.; Zyrnicki, W. Investigation of major and trace elements and their distributions between lipid and non-lipid fractions in Brazil nuts by inductively coupled plasma atomic optical spectrometry. Food Chem. 2008, 111, 1012-1015. [CrossRef]

22. Muller, A.L.H.; Müller, C.C.; Lyra, F.; Mello, P.A.; Mesko, M.F.; Muller, E.I.; Flores, E.M.M. Determination of toxic elements in nuts by inductively coupled plasma mass spectrometry after microwave-induced combustion. Food Anal. Methods 2012, 6, 258-264. [CrossRef]

23. Abbas, G.; Murtaza, B.; Niazi, N.K.; Shahid, M.; Niazi, N.K.; Khan, M.I.; Amjad, M.; Hussain, M.N. Arsenic Uptake, toxicity, detoxification, and speciation in plants: Physiological, Biochemical, and molecular aspects. Int. J. Environ. Res. Public Health 2018, 15, 59. [CrossRef]

24. Hashempour-Baltork, F.; Hosseini, H.; Houshiarrad, A.; Esmaeili, M. Contamination of foods with arsenic and mercury in Iran: A comprehensive review. Environ. Sci. Pollut. Res. 2019, 26, 25399-25413. [CrossRef]

25. Sterckeman, T.; Thomine, S. Mechanisms of Cadmium Accumulation in Plants. Crit. Rev. Plant Sci. 2020, 39, 322-359. [CrossRef]

26. Clemens, S.; Aarts, M.G.; Thomine, S.; Verbruggen, N. Plant science: The key to preventing slow cadmium poisoning. Trends Plant Sci. 2013, 18, 92-99. [CrossRef]

27. World Health Organization (WHO). Cadmium. In Safety Evaluation of Certain Contaminants in Food; WHO Food Additives Series, No. 64/FAO JECFA Monographs; WHO: Geneva, Switzerland, 2011.

28. Elloumi, N.; Zouari, M.; Chaari, L.; Jomni, C.; Marzouk, B.; Ben Abdallah, F. Effects of cadmium on lipids of almond seedlings (Prunus dulcis). Bot. Stud. 2014, 55, 61. [CrossRef] [PubMed]

29. Arpadjan, S.; Momchilova, S.; Venelinov, T.; Blagoeva, E.; Nikolova, M. Bioaccessibility of Cd, Cu, Fe, Mn, Pb, and Zn in hazelnut and walnut kernels investigated by an enzymolysis approach. J. Agric. Food Chem. 2013, 61, 6086-6091. [CrossRef] [PubMed]

30. Ni, Z.; Tang, F.; Yu, Q.; Liu, Y. Toxic and essential elements in five tree nuts from Hangzhou market, China. Food Addit. Contam. Part B 2016, 9, 246-250. [CrossRef] [PubMed]

31. EFSA. Lead dietary exposure in the European population. EFSA J. 2012, 10, 2831. [CrossRef]

32. Waheed, S.; Siddique, N. Evaluation of dietary status with respect to trace element intake from dry fruits consumed in Pakistan: A study using instrumental neutron activation analysis. Int. J. Food Sci. Nutr. 2009, 60, 333-343. [CrossRef]

33. Wang, W.; Gong, Y.; Greenfield, B.K.; Nunes, L.M.; Yang, Q.; Lei, P.; Bu, W.; Wang, B.; Zhao, X.; Huang, L.; et al. Relative contribution of rice and fish consumption to bioaccessibility-corrected health risks for urban residents in eastern China. Environ. Int. 2021, 155, 106682. [CrossRef] [PubMed]

34. Chung, K.H.; Shin, K.O.; Hwang, H.J.; Choi, K.-S. Chemical composition of nuts and seeds sold in Korea. Nutr. Res. Pr. 2013, 7, 82-88. [CrossRef]

35. Gutiérrez, A.J.; Rubio, C.; Moreno, I.M.; Gonzalez, A.G.; Gonzalez-Weller, D.; Bencharki, N.; Hardisson, A.; Revert, C. Estimation of dietary intake and target hazard quotients for metals by consumption of wines from the Canary Islands. Food Chem. Toxicol. 2017, 108, 810-818. [CrossRef] [PubMed]

36. Moreda-Piñeiro, J.; Herbello-Hermelo, P.; González, M.R.D.; Bermejo-Barrera, P.; Moreda-Piñeiro, A. Bioavailability assessment of essential and toxic metals in edible nuts and seeds. Food Chem. 2016, 205, 146-154. [CrossRef]

37. Da Silva, M.J.; Paim, A.P.S.; Pimentel, M.F.; Cervera, M.L.; de la Guardia, M. Determination of total mercury in nuts at ultratrace level. Anal. Chim. Acta 2014, 838, 13-19. [CrossRef]

38. Han, Y.; Ni, Z.; Li, S.; Qu, M.; Tang, F.; Mo, R.; Ye, C.; Liu, Y. Distribution, relationship, and risk assessment of toxic heavy metals in walnuts and growth soil. Environ. Sci. Pollut. Res. 2018, 25, 17434-17443. [CrossRef] 
39. Taghizadeh, S.F.; Rezaee, R.; Badibostan, H.; Karimi, G. Probabilistic carcinogenic and non-carcinogenic risk assessment of heavy metal ingestion through consumption of different walnut cultivars: An Iranian study. Environ. Monit. Assess. 2020, 192, 599. [CrossRef]

40. Wu, S.; Shen, D.; Wang, R.; Han, Y.; Zheng, Y.; Ni, Z.; Tang, F.; Mo, R.; Liu, Y. Evaluation of risk levels of trace elements in walnuts from China and their influence factors: Planting area and cultivar. Ecotoxicol. Environ. Saf. 2020, 203, 110996. [CrossRef] [PubMed] 